\title{
An Econometric Model Incorporating The Supply-Side Effects of Economic Policy
}

\author{
MICHAEL K. EVANS
}

This paper summarizes the principal findings of the new macroeconomic supply-side model which I have recently completed at Evans Economics. Rather than describe each individual equation or even blocks of equations, I have selected an alternative approach. Since the main thrust of the supply-side model is to examine the ways in which total productive capacity can be increased, I first examine the determinants of productivity, and then show how these determinants are estimated within the confines of the model. The bulk of this paper is devoted to the discussion of the productivity function, the investment functions, and the labor market functions. The concluding section then examines some alternative solutions generated by changes in monetary and fiscal policies. Rather than examine the usual full-scale multiplier tables, I have chosen to concentrate on a specific set of policy alternatives which should be able to increase productive capacity and employment while at the same time reducing inflation.

\section{DETERMINANTS OF PRODUCTIVITY}

As part of the supply-side model, we have estimated an econometric equation to explain changes in productivity on an endogenous basis. Previous attempts to explain productivity reached the conclusion that while some of the decline could be tied to the reduction in the investment ratio and other endogenous factors, part of it could not be explained by economic variables. However, we have found that not to be the case.

The function we have estimated relates the annual percentage change in productivity to two sets of variables: short-term cyclical variables and long-term secular factors. The short-term variables are a) percentage change in real GNP, and b) a nonlinear term of capacity utilization which takes the form $(95-\mathrm{CP})^{1 / 2}$. Essentially this term represents the fact that productivity growth slows down as

Michael Evans is President of Evans Economics, Ine., Washington, D.C. 
the economy approaches full employment and full capacity because of shortages and bottlenecks, more overtime and hence more worker errors, and hiring of less skilled and trained workers.

The long-term secular factors which we consider, together with the weights which we have assigned to each of them, are as follows:

1. Decline in the investment ratio

2. Costs of government regulation $1 \%$

3. Increase in secondary workers in the labor force $1 / 2 \%$

4. Increase in relative price of energy

5. Reduction in ratio of $R \& D$ expenditures to GNP

$1 / 2 \%$
$1 / 2 \%$
(included in \#1;
not measured
separately)

While the last factor was not explicitly included in the function because of the very long lag times involved, it enters the function indirectly through its eventual effect on investment. This point is discussed in more detail in the next section.

The actual equation used in our supply-side model is as follows:

$\begin{array}{lccrc}\begin{array}{l}\text { Independent } \\ \text { Variable }\end{array} & \begin{array}{c}\text { Estimated } \\ \text { Coefficient }\end{array} & \begin{array}{c}\text { Standard } \\ \text { Error }\end{array} & \text { T-Statistic } & \begin{array}{c}\text { Contribution } \\ \text { To R }^{2}\end{array} \\ \text {-C- } & -7.51592 & 4.57449 & -1.64301 & \\ \text { SECWK01 } & -0.839850 & 0.355811 & -2.36038 & 0.698377 \mathrm{D}-01 \\ \text { INVXC01 } & 0.625840 & 0.419031 & 1.49354 & 0.379613 \mathrm{D}-01 \\ \text { REG } & -0.208791 & 0.170205 & -1.22671 & 0.188628 \mathrm{D}-01 \\ \text { ENERGYC } & -4.11652 & 2.49016 & -1.65311 & 0.342554 \mathrm{D}-01 \\ \text { GNP72 } & 0.524536 & 0.108446 & 4.83686 & 0.293259 \\ \text { CAPUTIL } & 1.11549 & 0.440452 & 2.53261 & 0.804009 \mathrm{D}-01 \\ \text { R-Squared }=0.7368 & & & \\ \text { R-Squared (Corrected) }=0.6616 & & \\ \text { Multicollinearity Effect }=0.2122 & & \\ \text { Durbin-Watson Statistic }=1.3901 & & \\ \text { Number of Observations }=28 & & \\ \text { Sum of Squared Residuals }=17.7071 & & \\ \text { Standard Error of the Regression }=0.918256 & \end{array}$

The dependent variable is:

$\mathrm{PRDT}=\frac{\triangle \mathrm{PRD}}{\mathrm{PRD}_{-1}}$

where PRD $=$ Private nonfarm business productivity. 
The independent variables are:

SECWK01 $=\frac{1}{2} \sum_{i=0}^{2}$ SECWORK $_{-i}$

where SECWORK $=\frac{\text { Secondary workers }}{\text { Total employment }}$

INVXC01 $=\frac{1}{2} \sum_{i=1}^{2}$ INVXC $_{-i}$

where $\mathrm{INVXC}=$ Business Fixed Investment less investment in cars and trucks

Gross National Product

ENERGYC $=\Delta\left(\frac{\text { PWIFP }}{\text { PGNP }}\right)$

where PWIFP = Producer Price Index, fuel and power

PGNP = Implicit Deflator, Gross National Product

$\mathrm{GNP72}=\frac{\triangle \mathrm{GNP}}{\mathrm{GNP}_{-1}}$

where GNP $=$ Gross National Product, billions of 1972 dollars

CAPUTHL $=(95-\mathrm{CP})^{1 / 2}$

where $\mathrm{CP}=$ Index of Capacity Utilization, manufacturing

At first glance, the ratio of fixed business investment to GNP has remained roughly constant over the postwar period and in fact posted an above-average value for 1979 . However, this ratio is misleading and must be adjusted for several factors.

First, the ratio should be calculated in constant rather than current dollars. Just because the price of capital goods has increased faster than other prices does not mean that we are devoting more of our resources to capital formation.

Second, the investment figure should exclude capital spending undertaken to meet federally-mandated standards. The only figures available in this category are those for pollution abatement and control, so our estimate obviously understates total capital spending in this area. However, removal of these figures makes a noticeable difference to the investment ratio. 
FIGURE 1

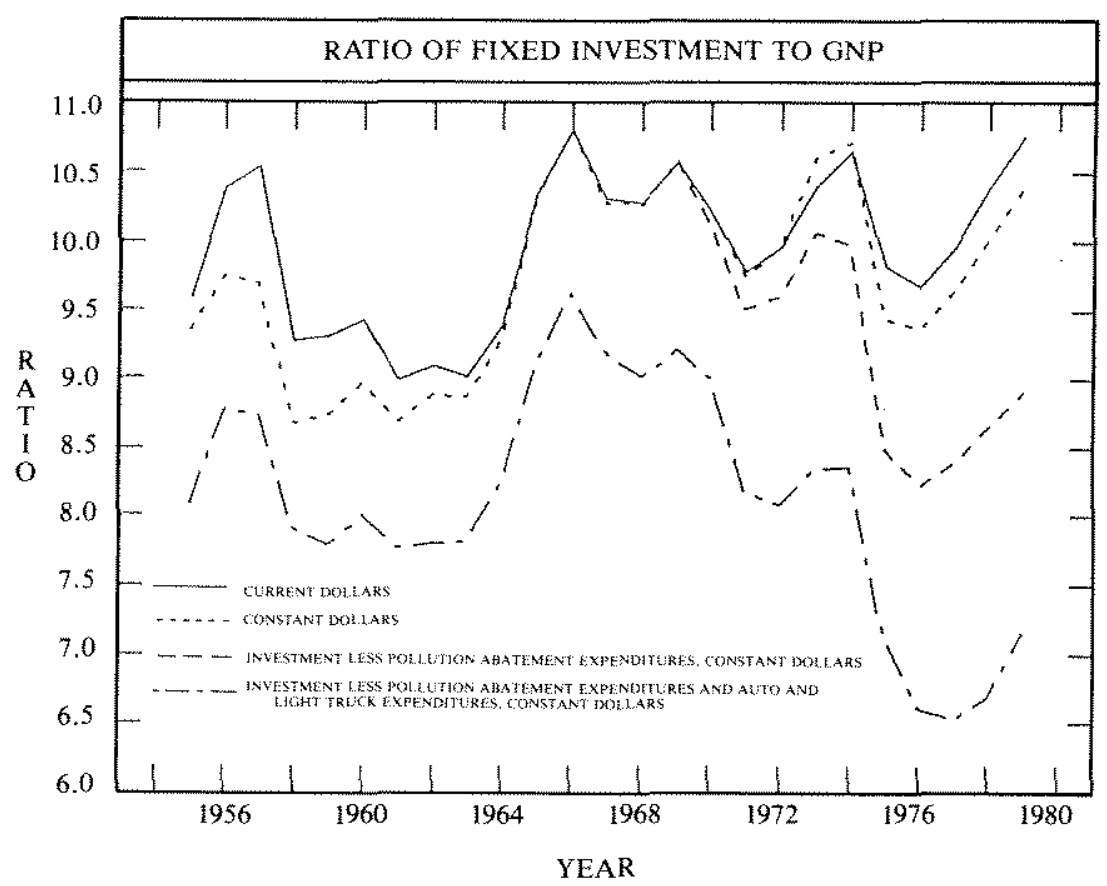

Third, "investment" in cars and light trucks should be excluded from the total investment figures. Most of these purchases are made for personal or quasi-business reasons, and do not represent investment in the traditional sense.

We have adjusted the investment ratio for all of these factors, and the very considerable difference which it makes is shown in Figure 1. Thus although the nominal ratio may not have declined, the real ratio of capital spending to GNP properly adjusted exhibits a striking demise for the past five years.

Our productivity equation suggests that a $1 \%$ increase in the investment ratio, or a switch of about $\$ 25$ billion (in 1980 dollars) from consumption to investment would raise productivity by about $0.6 \%$ per year and thus lower inflation by about twice that amount. We defer discussion of the ways in which this could be accomplished until the next section, turning now to the other principal determinants of productivity.

The second factor causing reduced growth in productivity, namely increased investment to meet federally-mandated standards, is summarized in Table 1 . This table should also include investment 


\section{TABLE 1}

Fixed Investment and Capital Stock

Adjustment for Inflation and Pollution Control Equipment

\begin{tabular}{|c|c|c|c|c|c|c|c|}
\hline Year & $\begin{array}{c}\text { Fixed } \\
\text { Business } \\
\text { Investment } \\
\text { (Current } \$ \text { ) }\end{array}$ & $\begin{array}{c}\text { Pollution } \\
\text { Control } \\
\end{array}$ & $\begin{array}{l}\text { Health } \\
\text { and } \\
\text { Safety }\end{array}$ & $\begin{array}{l}\text { Productive } \\
\text { Fixed } \\
\text { Business } \\
\text { Investment } \\
\text { (Current \$) }\end{array}$ & $\begin{array}{l}\text { Productive } \\
\text { Fixed } \\
\text { Business } \\
\text { Investment } \\
\text { (Constant \$) }\end{array}$ & $\begin{array}{c}\text { ¿Net } \\
\text { Capital } \\
\text { Stock } \\
\text { (Constant \$) }\end{array}$ & $\begin{array}{c}\text { Net } \\
\text { Productive } \\
\text { Capital } \\
\text { Stock } \\
\text { (Constant \$) }\end{array}$ \\
\hline 1970 & 100.5 & 2.2 & $1.7^{*}$ & 96.6 & 105.8 & 833.7 & 830.0 \\
\hline 1971 & 104.1 & 2.9 & $1.8^{*}$ & 99.4 & 103.2 & 859.5 & 851.4 \\
\hline 1972 & 116.8 & 4.1 & 2.5 & 110.2 & 110.2 & 889.8 & 875.8 \\
\hline 1973 & 136.0 & 5.3 & 2.6 & 128.1 & 123.4 & 929.5 & 908.5 \\
\hline 1974 & 150.6 & 5.8 & 3.1 & 141.7 & 122.7 & 965.1 & 936.7 \\
\hline 1975 & 150.2 & 6.5 & 2.7 & 141 & 106.6 & 981.2 & 944.9 \\
\hline 1976 & 164.6 & 6.8 & 2.4 & 155.4 & 112.2 & 1000.8 & 956.1 \\
\hline 1977 & 190.4 & 7.5 & 2.9 & 180 & 122.9 & 1029.0 & 973.7 \\
\hline 1978 & 221.1 & 6.9 & 4.3 & 209.9 & 143.3 & 1060.2 & 993.7 \\
\hline 1979 & 254.9 & 7.1 & 2.9 & 244.9 & 155.3 & $1089.3^{*}$ & 1024.8 \\
\hline $1980 \mathrm{E}$ & 264.2 & 7.7 & 3.7 & 252.8 & 147.6 & $1110.7^{*}$ & 1044.3 \\
\hline
\end{tabular}

June, 1980 Survey of Current Business.

b Annual Survey of Investment in Employee Safety and Health, McGraw-Hill Publications Company, 1980.

${ }^{c}$ August, 1979 Survey of Current Business.

* Extrapolated by Evans Economics, Inc.

All figures are in bitlions of dollars. 
undertaken by the automobile industry to meet pollution, fuel economy, and safety standards, but we were unable to find even approximate estimates for these figures. Even without them, however, we note that adjusted capital stock has grown at an annual rate of only $2.4 \%$ since 1970 , compared to $3.0 \%$ as calculated from the investment figures before adjustment .

Because pollution control costs represent the lion's share of nonproductive investment, we have presented them in greater detail in Table 2. As shown there, investment in private sector pollution control for stationary source emissions (i.e., excluding motor vehicles) will average about $4 \%$ of investment over the 1973-1984 period. Public sector spending for pollution control will average between $15 \%$ and $20 \%$ of total public sector investment, while pollution control devices will represent about $10 \%$ of the cost of purchasing a new car.

We also repeat the annual costs associated with pollution control investment; they are defined to include interest, depreciation, and operation and maintenance costs. According to Council on Environmental Quality (CEQ) estimates, the total annual costs for the 1975-1984 period will be $\$ 486$ billion in 1975 dollars, or approximately $\$ 750$ billion in current dollars. These costs will amount to between $2 \%$ and $3 \%$ of total GNP during the forthcoming decade, representing a very significant economic burden for the costs of clean air, water, and solid waste.

Two additional comments should be appended to these figures. First, the cost of regulation appearing in the government budgets is only a tiny fraction of the cost imposed on the private sector of the economy; Murray Wiedenbaum and others have estimated that it is only about $5 \%$. Second, while pollution abatement probably does represent the lion's share of these costs, the burden of occupational safety and health standards, consumer product safety, toxic substances control act, and other programs are substantial and should not be assumed to be zero just because no definite figures are available for these categories.

We do not think it is reasonable to expect society to turn back the clock on the massive changes in social policy which produced the federally-mandated standards of the 1970s. Yet it certainly should at least be possible to rationalize these regulations so that firms are charged with attaining the ends rather than the means. If, for example, one national goal is to reduce air pollution, utilities ought to be able to decide on their own whether this is to be accomplished through choice of fuel, use of scrubbers, less 
TABLE 2

Total Actual and Expected Investment for Pollution Control, 1970-1984

\begin{tabular}{|c|c|c|c|c|c|c|c|c|c|c|}
\hline \multirow[b]{2}{*}{ Year } & (1) & \multicolumn{2}{|c|}{ Capital Investment } & \multicolumn{3}{|c|}{ Annual Cost $5^{* *}$} & \multirow{2}{*}{$\begin{array}{c}\text { (7) } \\
\text { Total } \\
\text { Fixed } \\
\text { Business } \\
\text { Investment }\end{array}$} & \multirow{2}{*}{$\begin{array}{c}\text { (8) } \\
\text { Pollution } \\
\text { Control } \\
\text { Investment } \\
\text { (Percent) } \\
\end{array}$} & \multirow{2}{*}{$\begin{array}{c}\text { (9) } \\
\text { Total } \\
\text { GNP }\end{array}$} & \multirow{2}{*}{$\begin{array}{c}\text { (10) } \\
\text { Pollution } \\
\text { Control } \\
\text { Resource } \\
\text { (Percent) }\end{array}$} \\
\hline & $\begin{array}{l}\text { Station } \\
\text { Private }\end{array}$ & $\begin{array}{l}\text { Source } \\
\text { Public }\end{array}$ & $\begin{array}{l}\text { Mobile } \\
\text { Source }^{*}\end{array}$ & $\begin{array}{l}\text { aStatio } \\
\text { Private } \\
\end{array}$ & $\begin{array}{l}\text { Source } \\
\text { Public }\end{array}$ & $\begin{array}{l}\text { Mobile } \\
\text { Source* }\end{array}$ & & & & \\
\hline 1970 & 2.2 & 0.1 & 0.3 & 1.1 & 0.0 & 1.3 & 100.5 & 2.2 & 982 & 0.2 \\
\hline 1971 & 2.9 & 0.1 & 0.4 & 1.7 & 0.0 & 2.0 & 104.1 & 2.8 & 1063 & 0.3 \\
\hline 1972 & 4.1 & 0.2 & 0.4 & 2.4 & 0.1 & 2.8 & 116.8 & 3.5 & 1171 & 0.5 \\
\hline 1973 & 5.3 & 0.5 & 1.1 & 3.5 & 0.3 & 4.1 & 136.0 & 3.9 & 1307 & 0.6 \\
\hline 1974 & 5.8 & 3.7 & 1.2 & 5.4 & 1.4 & 5.3 & 150.6 & 3.9 & 1413 & 0.9 \\
\hline 1975 & 6.5 & 6.6 & 2.3 & 8.2 & 3.3 & 5.7 & 150.2 & 4.3 & 1529 & 1.1 \\
\hline 1976 & 6.8 & 8.0 & 2.9 & 11.4 & 7.4 & 6.0 & 164.6 & 4.1 & 1700 & 1.5 \\
\hline 1977 & 7.5 & 6.0 & 3.5 & 15.3 & 10.3 & 6.4 & 190.4 & 3.9 & 1887 & 1.7 \\
\hline 1978 & 8.9 & 6.7 & 5.6 & 20.6 & 14.2 & 8.2 & 221.1 & 4.0 & 2104 & 2.0 \\
\hline 1979 & 11.0 & 7.0 & 6.3 & 25.3 & 17.2 & 11.3 & 242.1 & 4.5 & 2281 & 2.4 \\
\hline 1980 & 11.7 & 7.4 & 6.6 & 31.0 & 20.5 & 12.1 & 262.7 & 4.4 & 2479 & 2.6 \\
\hline 1981 & 12.2 & 7.8 & 7.2 & 37.7 & 25.0 & 12.2 & 299.7 & 4.1 & 2730 & 2.7 \\
\hline 1982 & 13.6 & 8.2 & 7.8 & 45.2 & 29.3 & 12.1 & 337.5 & 4.0 & 2980 & 2.9 \\
\hline 1983 & 15.0 & 8.6 & 8.4 & 53.3 & 37.4 & 11.7 & 376.6 & 4.0 & 3256 & 3.1 \\
\hline 1984 & 16.5 & 9.1 & 8.9 & 62.9 & 42.9 & 11.3 & 417.8 & 4.0 & 3551 & 3.3 \\
\hline
\end{tabular}

Sotrce: Figures are interpolated from ten-year totals given in the CEQ Annual Repont. At figures are converted from constant to current dollars. Numbers are based on total rather than incremental pollution control expenditures.

* Interest, Depreciation, Operation, and Matitenatice Costs of Pollution contol.

* Includes additional fuet costs, motor vehicles air, water, and solid waste, excludes motor vehicles $(8)=(1) /(7)$ 
production during "air alerts," building plants in new locations, and so forth, rather than by administrative fiat. Our best guess is that the use of common sense in these areas could reduce the loss in productivity growth due to regulation from $1 \%$ to $1 / 2 \%$ per year, thus reducing the overall rate of inflation by about $1 \%$ per year. If in addition this reduction from $\$ 100$ billion to $\$ 50$ billion per year would free resources for increased capital spending, the gains would be even larger.

The third factor which has accounted for the slowdown in productivity growth, although it will be reversed during the 1980s, is the sharp growth of secondary workers in the labor force. In 1964, males aged 25 to 54 accounted for $46 \%$ of the total labor force; in 1980 the figure will be $38 \%$. The major increases have occurred in women aged 25 to 54 and in teenagers of both sexes. The problem has been compounded not only by rapid increases in labor force participation rates but in the population aged under 25 .

Many of these secondary workers have less education, vocational training, or on-the-job experience than their primary counterparts when first hired. As a result, they were initially less productive. This does not necessarily imply that such individuals will continue to have a lower level of productivity over the lifetime of their jobs, but rather that their productivity was lower when they initially entered the labor market.

During the 1980s, however, the size of the population aged 16 to 24 will shrink by a full 6 million persons. Thus even if labor force rates continte to rise for teenage workers, the number of potential employees will decline significantly. Second, many women aged 25 to 54 in the labor force will have had the full complement of education, vocational training, and on-the-job experience as their male counterparts, so they will be just as productive. As a result, we look for this factor to improve, hence raising the growth rate of productivity for the 1980 s by about $1 / 2 \%$ per year.

The fourth factor retarding productivity, the skyrocketing cost of energy, is only too well known to anyone associated with the utility industry, but the increase as shown in Figure 2 is striking nonetheless. Furthermore, we find little if any reason to expect this ratio to reverse course over the next 10 years. In the U.S., consumption of petroleum products remains at a high level, although not as much as previously, and production is stagnant. Under these two sets of circumstances it is clear that the longwrun trend for oil imports continues in the upward direction, which gives OPEC all the economic justification they need to continue to raise prices in real terms. In this respect it is noteworthy that OPEC was 
FIGURE 2

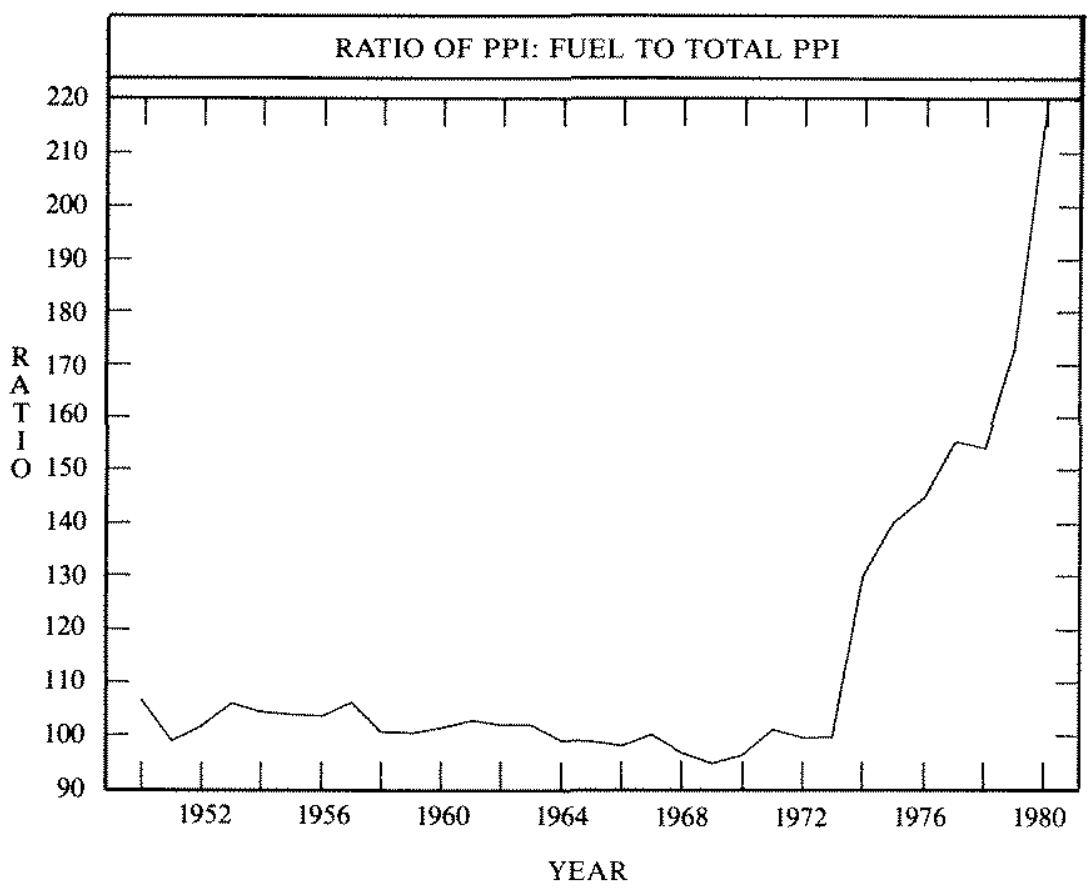

able to push through yet another price increase in June in spite of the fact that the U.S. is definitely in the midst of a fairly serious recession and the rest of the world economy is also slowing significantly.

The long-run effects of energy prices on productivity are undoubtedly understated. Indeed, it has become increasingly apparent that the long-term effects of changes in energy prices on productivity are greater than had been generally appreciated, and larger than would be determined by empirical techniques which are by nature restricted to the period since 1973. The productivity equation which we have estimated in our supply-side model indicates that the increase in energy costs has lowered productivity growth by $1 / 2 \%$ per year. While that is probably the appropriate figure for the short run, the long-run figure is considerably greater.

The standard explanation of how higher energy costs reduce productivity is usually confined to the manufacturing sector. With a shift in relative prices, firms use less energy and more labor, raw materials, and capital. This shift is borne out by the increase in 
employment throughout 1979 during a period of virtually stagnant output, and while some of the excess workers are being disgorged now that we are in a recession, the demand for labor still has shifted to a higher plane.

This shift is an important change and one which cannot be treated lightly. Yet in the longer run it will probably turn out to be less important than the changes in productivity which affect the transportation and distribution network. Some of these changes are already obvious, such as the 1974-75 decline in productivity in the transportation industry when higher fuel prices led to lower speeds by airlines (voluntary) and trucking (mandatory). However, these short-run changes are already included in our measurements of the $1 / 2 \%$ yearly decline. Here we consider the longer term changes brought about by higher energy prices as they affect the entire production and distribution system of the economy.

Let us first consider a world in which transportation and distribution costs are negligible. If that were the case, the location of manufacturing plants would be largely independent of markets except for those products that gain weight or bulk during manufacturing or those processes which utilize large quantities of raw materials. Most important, all plants would be large enough to take full advantage of economies of scale. Hence there would be relatively few plants in those industries where economies of scale are significant, particularly metals, machinery, transportation equipment, and power generation. Competition would thrive because one firm could not obtain an advantage merely by accident of location. The manufacturing sector would not be the only part of the economy to benefit from this arrangement. Consumers would also benefit; they could comparison shop at several locations since the cost of a reasonable amount of travel to obtain better prices would be small.

While transportation costs have always been a substantial portion of the total price for some goods, such as cement, it is not too farfetched to say that many elements of the economy described above applied to the U.S. before 1973. Indeed, it should be clear in general that cheap transportation and distribution aids productivity and retards inflation. It encourages greater efficiency through economies of scale in manufacturing, and it encourages greater competition through a wider range of choice in retail markets. After all, if consumers had no transportation and were virtually forced to shop only at the closest store, the storekeeper would have far less incentive to cut costs through higher productivity.

Thus the higher cost of energy, through reducing the amount of 
transportation utilized, raises prices by much more than the cost of the more expensive fuel alone. Furthermore, this is not reflected in higher profits; it is the deadweight loss of productivity which does not benefit anyone. Manufacturing plants gradually become less efficient, and retail outlets become less competitive and less productive.

Obviously these events change only very slowly over time, which is precisely why we cannot yet measure them very well. Existing plants do not shrink when energy costs rise, although they may run at lower rates of capacity utilization. Consumers do not change their driving or living habits overnight, and so on. But over time these gradual changes, almost imperceptible within the time frame of a quarter or even a year, cumulate and eventually represent a potent force affecting productivity.

Offsetting this to a certain degree is the fact that if capital spending is stimulated during the $1980 \mathrm{~s}$, much of the new investment may be used for energy-saving platt and equipment, thus diminishing our dependence on imported oil. This would eventually cause OPEC to reduce their price in real terms, hence removing one of the major hurdles to higher productivity growth. In other words, higher investment may have benefits far greater than the traditional methods of raising productivity through expanded capital stock; the new mix of capital stock may be more energy-efficient as well, representing savings which would not come about were new investment to proceed at a slower pace. However, the entire relationship between energy prices and investment is a very complicated one, well beyond the scope of this modest report.

The fifth factor which we believe influences the long-term growth rate of productivity is the proportion of resources devoted to $R \& D$ compared to GNP. As is shown in Figure 3, from a peak of $3 \%$ reached in the mid-1960s at the height of the space program, this ratio has declined to slightly over $2 \%$ in 1976 , although it has recently improved as private industry has stepped up its R\&D spending. The long lags between $R \& D$ spending and productivity growth, which average up to five years, mean that this relationship is not quite as precise as the other factors determining productivity. However, as discussed in the next section, it is thought to have an effect on investment, albeit with this very long lag.

To summarize this section, output/manhour in the private sector increased at an annual average rate of $3 \%$ for the period from 1948 to 1965 , but has declined to almost $0 \%$ currently. Table 3 contains the tabulation of the postwar record for increases in output/ manhour in the private nonfarm sector. We have taken three-year 
FIGURE 3

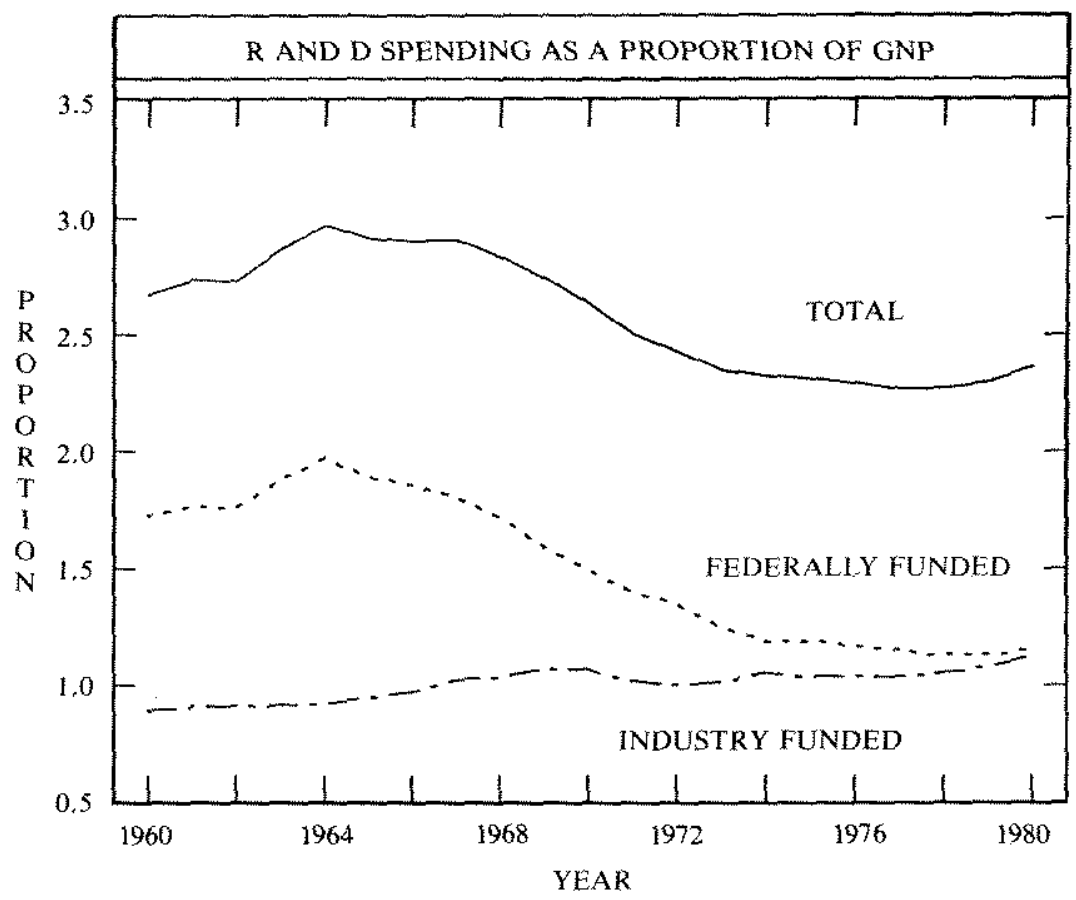

averages rather than yearly figures in order to smooth out the fluctuations in productivity caused by sharp changes in output. While some traces of recessions still remain in these numbers, the overall swings in productivity emerge much more clearly than is the case in the series for annual changes.

As shown in Table 3, productivity rose very rapidly in the years immediately following World War II (no figures are available before 1948) because of the large proportion of GNP devoted to investment to replace obsolete plant and equipment. Productivity increases then declined to the $2.0 \%$ range for the period 1956-1961, considerably below the long-term average. This was due in large part to the severity of the 1958 recession. Productivity then rose rapidly from the period 1962 to 1968 , due to the increase in capital spending spurred by the investment tax credit, liberalized depreciation allowances, and the reduction in the corporate income tax rate; productivity gains were also increased by the substantial increases in federal spending for research and development. Beginning in 1969, both of these driving forces toward higher growth were removed. The investment tax credit was cancelled, and 
TABLE 3

Long-Term Trends in Productivity Growth

Average Annual Growth Rate

Three-Year Period in Productivity (Private Nonfarm Sector)

\begin{tabular}{ll}
\hline 1950 & 4.2 \\
1951 & 4.0 \\
1952 & 3.5 \\
1953 & 2.2 \\
1954 & 2.0 \\
1955 & 2.4 \\
1956 & 1.6 \\
1957 & 1.6 \\
1958 & 1.7 \\
1959 & 2.8 \\
1960 & 2.3 \\
1961 & 2.4 \\
1962 & 2.7 \\
1963 & 3.5 \\
1964 & 3.5 \\
1965 & 3.0 \\
1966 & 3.1 \\
1967 & 2.4 \\
1968 & 2.4 \\
1969 & 1.3 \\
1970 & 1.5 \\
1971 & 2.1 \\
1972 & 2.3 \\
1973 & 2.9 \\
1974 & 0.8 \\
1975 & 0.2 \\
1976 & 0.8 \\
1977 & 2.3 \\
1978 & 1.9 \\
1979 & 0.3 \\
1980 & 0.6 \\
$1981-1990$ &
\end{tabular}


recurring financial crises reduced the amount of money available for new investment spending. The reinstatement of the investment tax credit in 1971 did raise investment above the levels which would otherwise have been reached, but this was offset by the substantial expenditures required for environmental and safety standards. As a result, productivity actually declined for the first time in the postwar period in 1974 and for the three-year period 1973-1975 showed virtually no improvement. While the 1977-78 figures indicate a rebound, that was due mainly to cyclical factors, as shown by the subsequent slowdown in 1979 and 1980 .

The growth rate of productivity in the 1980 s clearly depends on what happens to the factors we enumerated at the beginning of this section.

\section{DETERMINANTS OF INVESTMENT}

It is generally agreed that an increase in the production of resources devoted to capital spending will raise productivity, hence increasing real growth and lowering inflation. However, less agreement exists concerning the determinants of investment. Economists are generally divided into two groups: those who believe in the "trickle-down" theory, and those who claim that the primary variable is expected rate of return.

The trickle-down theory states that a rise in consumption is sufficient to increase investment to the desired level. Once the demand for goods increases, businessmen, ever alert and eager for increased opportunities, will expand capacity sufficiently to create the productive capacity for these new goods. In somewhat oversimplified terms, demand creates its own supply.

The rate of return theorists would argue that no such automatic mechanism exists to equilibrate demand and supply. Capital spending will not increase unless the expected rate of return is sufficient to cover the cost of investment. To be sure, an increase in demand does raise the rate of return, other things being equal-but it does not in and of itself guarantee an adequate rate of return. Thus the tax mechanism must be used to insure that demand and supply are kept in balance. Obviously the choice of theory has tremendous implications in determining the appropriate tax policies to stimulate growth and productivity.

The investment functions which we have estimated in the Evans Economics macro model rely heavily on the cost of capital-rate of return variable originally introduced by Jorgenson. However, the approach which we have used permits much greater flexibility than 
his original construction. By using a two-step procedure in which we estimate equations for orders and investment separately, we are able to measure the separate contributions for a change in the corporate income tax rate, investment tax credit, and depreciation allowances. Furthernore, since the index of stock prices is included as one of the variables in the rental cost of capital term, we can also examine how changes in the capital gains tax rate will affect investment.

We can summarize the results here by listing the impact effects of changes in these tax laws. By impact effects we mean simply the marginal coefficients times the change in the tax law in question. These coefficients do not take into account the interactive and dynamic effects, for which we need to solve the entire model, but they do give some idea of both the absolute and relative importance of each type of tax change.

Our results in the supply-side model have shown that, for the same reventue-producing change, the corporate income tax rate cut has greater efficacy than a change in depreciation allowances, which in turn has a greater effect than a change in the investment tax credit. Furthermore, a change in the stock prices has a substantially greater ef fect than a proportional change in interest rates. Since these findings are not universally accepted, a further word of explanation is in order.

We have found that the corpotate income tax cut has the highest efficacy because it is a "pure" tax cut; it does not contain any of the restrictions that the other types of tax changes contain. For example, an investment tax credit can be used only for equipment, but not for plant; a certain amount of the credit must be carried over into future years and in certain circumstances companies cannot use all the credit, which means they must find other investors who use the credit as a tax shelter. In addition, at least until recently many investors believed that the investment tax credit was a "gimmick" to be suspended or terminated at will by Congress, and hence they were less willing to use it as a basis for long-term investment planning.

While we do think that these three changes in the tax law will have sonewhat differing effects on investment, it should be stressed that all of them will have a significantly positive response. Indeed, the post-war history of capital spending in the U.S. economy is largely tied to changes in the effective tax rate on corporate income. The relationship between changes in capital spending (in constant prices) and the effective corporate income tax rate lagged one year is given in Figure 4. 
FIGURE 4

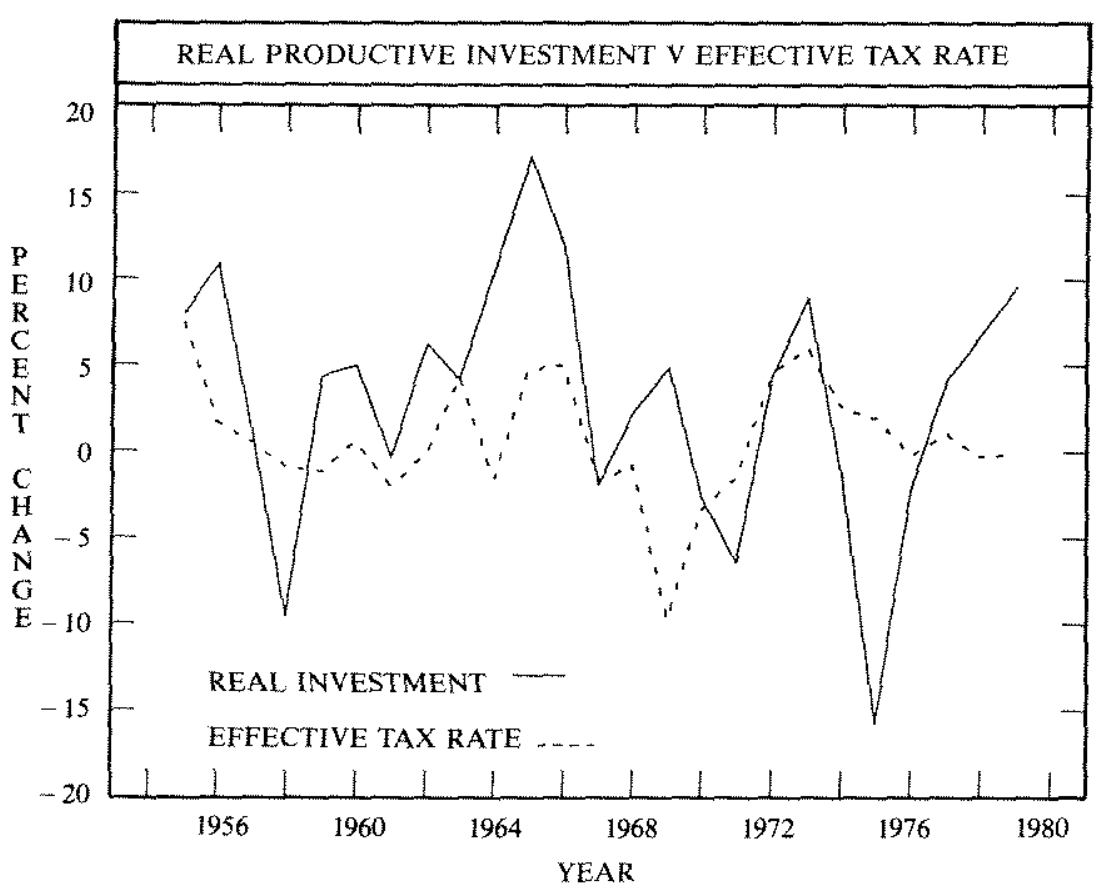

To summarize the information given in Figure 4, the U.S. economy has undergone three investment booms in the postwar period: 1955-1956, 1964-1966, and 1972-1973. Each of these booms has a common characteristic: it was preceded in the previous year by a major change in the tax code which was favorable to investment. Hence 1954 marked the end of the excess profits tax from the Korean War and the first liberalization of depreciation allowances. The investment tax credit was introduced at a $7 \%$ rate in late 1962 and was accompanied by a $20 \%$ reduction in accounting tax lives; when this was followed by a reduction in the corporate income tax tate from $52 \%$ to $48 \%$ in 1964 , capital spending climbed $20 \%$ in constant prices in 1965 , the only time in the postwar period that has occurred. Finally, in 1972 the investment tax credit was reinstated at $7 \%$ and accounting tax lives were reduced by an additional $20 \%$.

We also note that the sharp increase in tax rates in 1969 , caused by the imposition of the $10 \%$ income tax surtax and the suspension of the investment tax credit, was sufficient to cause a decline in 
FIGURE 5

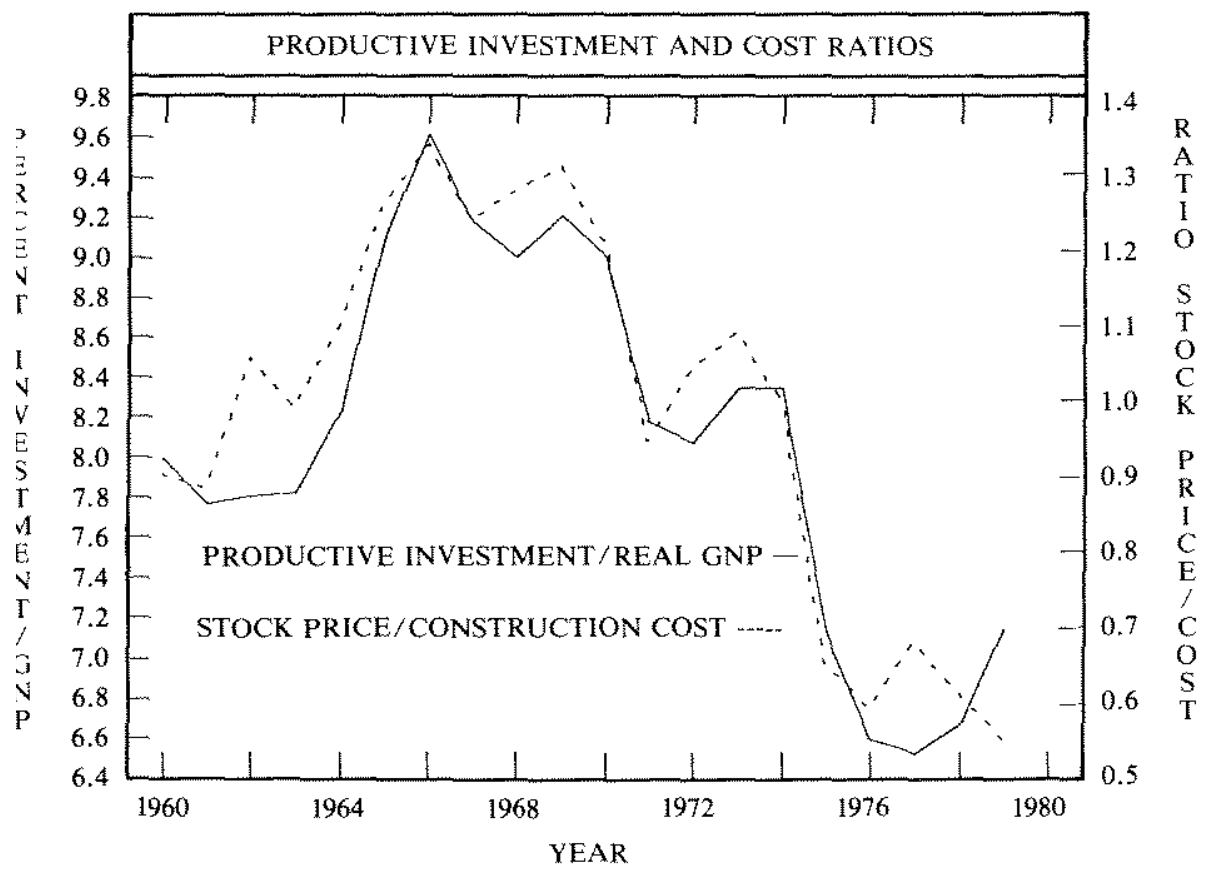

investment in 1970 even though the economy was still operating at high utilization rates.

However, the correlation between changes in investment and changes in the effective corporate income tax rate is not perfect. In particular, the sharp declines in investment in 1958 and 1975 appear to be unrelated to changes in the tax code, and were indeed caused by the severe recessions which occurred in those years.

This anomaly disappears when we correlate the investment ratio and the ratio of stock prices to construction costs, lagged one year. As shown in Figure 5, this ratio captures both the cyclical and secular movements in the investment ratio. This fact has received bipartisan support, as it was prominently discussed in both the 1977 and 1978 issues of the Economic Report of the President.

The theory behind this ratio is fairly straightforward. When stock prices are high relative to construction costs and equity capital is relatively inexpensive, businesses will expand by building new plants and filling them with new equipment. However, when stock prices are relatively depressed, businesses will expand by buying smaller 


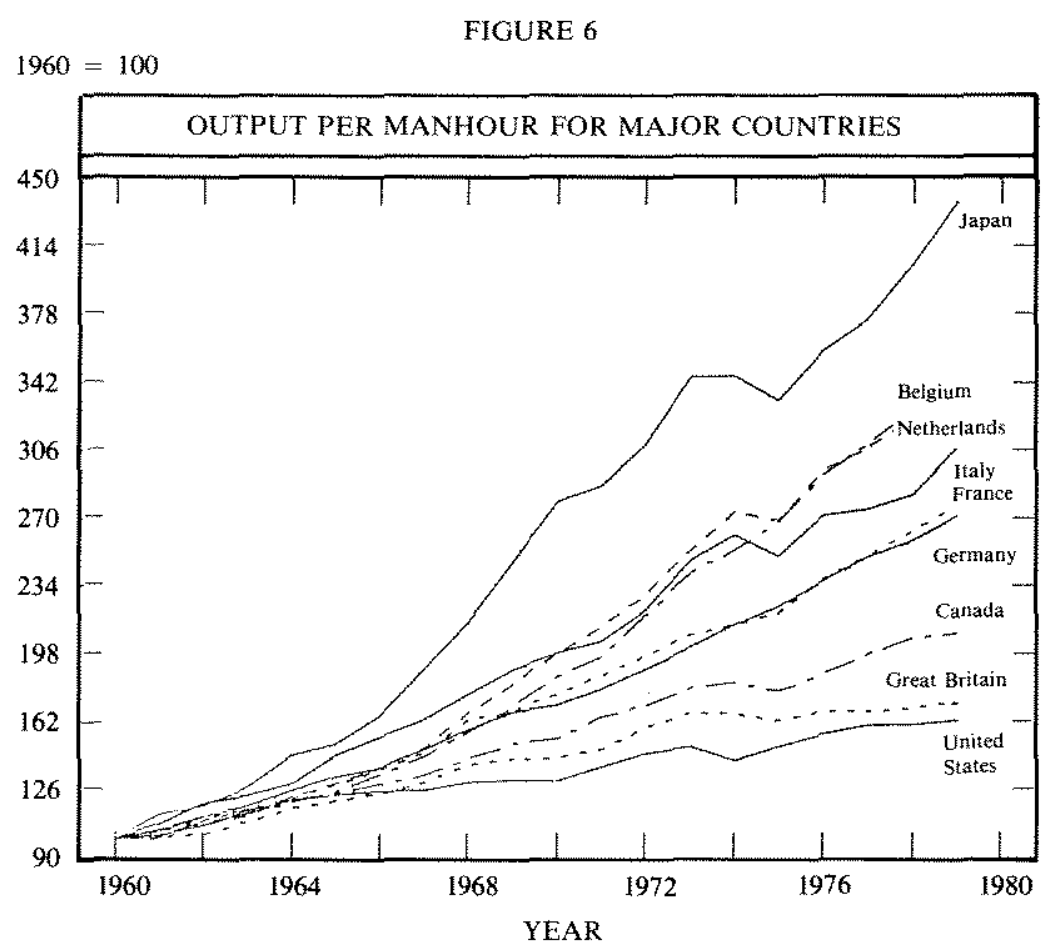

existing businesses, rather than by investing more in new capital assets. The course of the stock market is thus of extreme importance in determining the growth in investment, and explains why this term is relatively more important than the interest rate.

We can never be absolutely positive that the slowdown in productivity after 1966 was due to the reduced rate of growth in investment. However, additional supporting evidence can be gathered by examining the investment and growth patterns of the U.S. economy with those of other leading industrialized countries of the world. These comparisons are provided in the next two graphs. In Figure 6 we find almost a perfect correlation between the proportion of GNP spent on fixed investment and the growth in productivity. Figure 7 documents the extent to which increases in output/manhour in the U.S. have fallen behind growth in the rest of the world. Even when one adjusts these for lower wage gains in this country, the evidence explaining the weakness of the dollar seems compelling.

It often comes as a shock to realize that in the past 15 years the proportion of GNP going to fixed business investment and the rate 
FIGURE 7

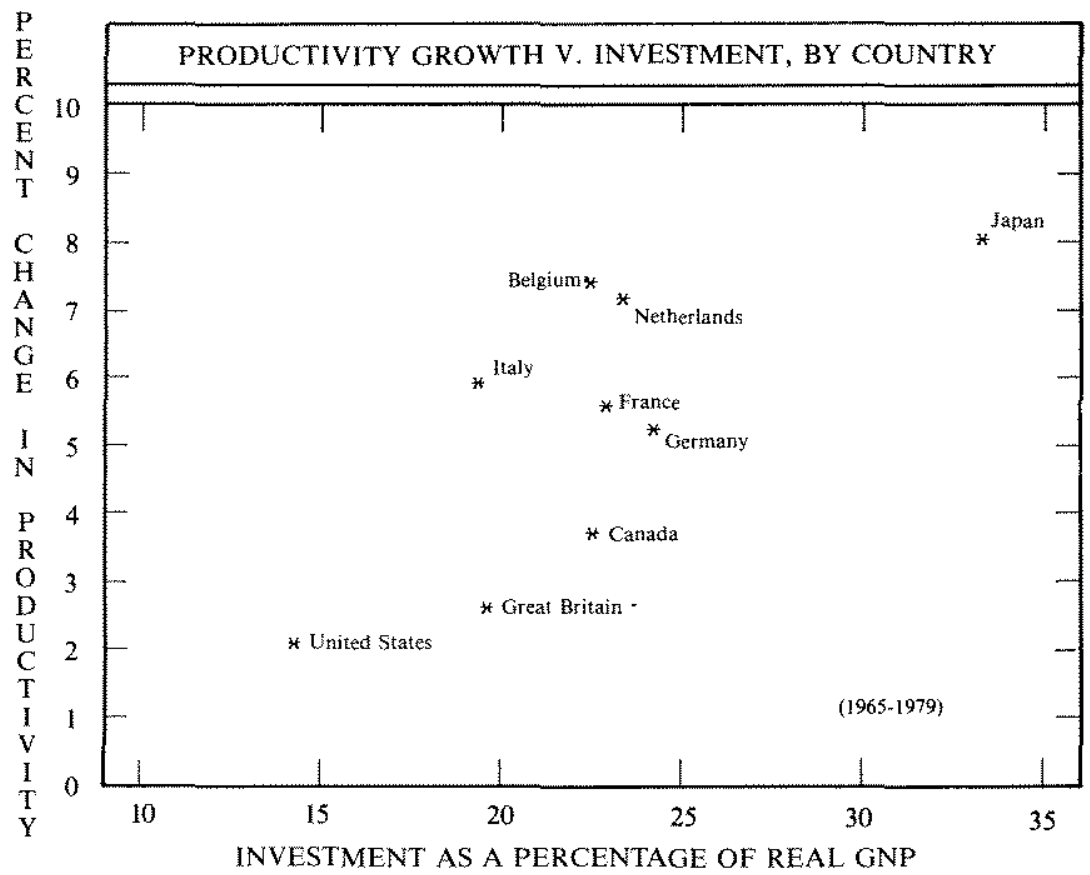

of increase in productivity for the United States are below even those of the United Kingdom. It is this below-par performance which has been at the root of the weakness of the dollar since 1970 .

The oil embargo and subsequent quintupling of OPEC oil prices may result in some relative shift in these relationships during the next decade. As shown in Figure 7, productivity declined in Japan and all major European countries except Germany during 1974, the first time this has occurred in the entire postwar period. Furthermore, wage gains in Europe and Japan have been well above increases in the U.S.; if this continues and is not offset by continuing relative increases in productivity, these areas could lose much of their allure for investors.

So far we have been discussing plans to stimulate investment directly through lower taxes. However, investment can also be stimulated indirectly, namely by increasing personal saving. A decline in the tax rate on income generated from saving-such as interest and dividend income-would result in more personal saving, and eventually more investment. 
The vast majority of previous empirical work on the consumption function implies that the interest rate has no significant effect on the proportion of disposable income which is consumed or saved. It is true that a simple correlation between the saving rate and the interest rate reveals no relationship. However, we have found a very strong link between the real after-tax rate of return and personal saving. After substantial testing, we have determined that this rate can best be represented by the long-term bond yield multiplied by (1 - average tax rate on personal income) minus the average rate of inflation over the past four years. Thus defined, this rate of return is found to have an important effect on consumption and saving. Specifically, a $1 \%$ increase in the rate of return-e.g., from $3 \%$ to $4 \%$ - would raise saving by $\$ 12$ billion. Furthermore, we find that the importance of the after-tax rate of return on savings has been increasing in recent years as interest rates and inflation move to higher levels.

An across-the-board $\$ 10$ billion personal income tax cut from, say $30 \%$ to $29 \%$ would have relatively little effect on saving over and above the increase stemming from higher income, although as we note later it would have a much larger effect on labor market behavior. However, the increase in saving from this tax cut due to the increased rate of return would be only about $\$ 1$ billion. On the other hand, a tax cut of the same size which was targeted only to increase saving through a higher rate of return would result in a rise in saving of some $\$ 13$ billion. Thus the form of the tax cut is allimportant in determining the effect on consumption and saving.

We now consider some of the ways in which saving and investment are stimulated in the high productivity simulation calculated for this report.

As mentioned above, the simplest and most direct approach is a reduction in the corporate income tax rate. A decrease from the present level of $46 \%$ to $40 \%$ would cost the Treasury about $\$ 1 i$ billion per year before reflows; these figures obviously increase over time as the economy expands and profits rise in nominal terms. The impact effect on investment would be to raise it $\$ 9$ billion after the lagged effects were fully considered. The multiplier effects are discussed in more detail in the final section.

Changes in depreciation lives could take several different forms, and in general the analysis is somewhat more complicated than for the simple cut in corporate income taxes. The two major plans which have been suggested for changing depreciation allowances are (a) replacement cost accounting, and (b) shortening tax lives, which 
has recently been popularized as $10-5-3$, although clearly other variants of shorter lives are possible.

The theoretical justification to adjust depreciation allowances, in addition to the fact that this would stimulate investment, is that these allowances fall far short of replacement needs in a period of inflation.

Since that is the avowed objective of all such plans, it seems most reasonable to us to meet the ravages of inflation by an adjustment which compensates for inflation. This would be accomplished very simply as follows. Depreciation allowances would be set equal to the appropriate proportion of investment for each year times the ratio of capital goods prices in the present year to capital goods prices in the year during which the investment was originally undertaken. Symbolically this can be expressed by:

$$
D_{T}=\sum_{j=0}^{T-1}\left(\frac{S L_{T-j}}{t_{T-j}}+A C C_{T-j}\left(\frac{2\left(t_{T-j}-j\right)}{t^{2} T-j}\right)\right) * \frac{P_{k_{T}}}{P_{k_{T}-j}} * I_{T-j}
$$

where

$\mathrm{P}_{\mathrm{k}_{\mathrm{T}}}=$ price of capital goods (implicit deflator, national income accounts, business fixed investment) in year $T$;

$\mathrm{D}_{\mathrm{T}}=$ depreciation allowances in year $\mathrm{T}$;

$\mathrm{SL}_{\mathrm{T}}=$ proportion of investment depreciated by the straight line method in year $\mathrm{T}$;

$\mathrm{t}_{\mathrm{T}}=$ average length of depreciable life of assets depreciated by the straight line method in year $T$;

$\mathrm{ACC}_{\mathrm{T}}=$ proportion of investment depreciated by accelerated methods in year $\mathrm{T}$; and

$\mathbf{I}_{\mathrm{T}}=$ investment in year $\mathrm{T}$.

The drawback to replacement cost accounting, according to the proponents of $10-5 m$, is that it is too complicated. However, we feel that such a plan could be implemented very simply by having all depreciation allowances increase by the average rate of inflation of capital goods, as published by the Bureau of Economic Analysis (BEA). Some distinction could be made for equipment and structures, but as a first order of approximation $90 \%$ of the inequities caused by inflation would be wiped out by linking to one or two overall indexes.

The reduction in the maximum capital gains tax rate from $49.1 \%$ 
to $28 \%$ in late 1978 brought forth anguished cries from some critics who claimed that it benefited the speculator rather than the longterm investor. While we believe that all capital gains taxes should eventually be abolished, the remaining tax burden could be restructured to benefit more directly those members of society who contribute most to spending on R\&D, venture capital, and investment in new companies.

One plan to restructure the capital gains tax laws states that anyone investing venture capital into a new or fledgling company and then holding on to the stock for five years or more would not have to pay any capital gains taxes at all. Furthermore, capital gains would be calculated on an indexed basis, so that investors would not have to pay tax on the phony profits which are due only to inflation. For purposes of calculation, the implicit GNP deflator or some other broad-based price index would be used.

In order to relate the relationship between stock market prices and investment to tax policy, we must determine how much a change in capital gains taxes will affect the stock market. Here we have found a significant relationship, namely that a $1 \%$ change in the maximum tax rate on capital gains (i.e., from $48 \%$ to $47 \%$ ) would raise stock prices by approximately $1 \frac{1 / 2}{2} \%$. Hence one of the most important ways to stimulate investment and productivity is to reduce the capital gains tax rate further.

Although no specific figures are available, it is likely that the reduction in capital gains taxes will also contribute to a renaissance of the venture capital industry, which was approximately a $\$ 3$ billion a year industry in 1968 before higher capital gains taxes and the dectine of the stock market combined virtually to wipe out this industry. R\&D spending has also been hampered by the lack of venture capital, and while this does not show up immediately in declining productivity, it is thought to have a very substantial effect over a five to 10 year period.

A number of plans have emerged to reduce the burden on the individual saver, and although these are not as far advanced through the Congressional labyrinth, they still merit some discussion and inclusion in our model simulations.

The formation of Individual Retirement Accounts (IRAs) four years ago permitted individuals not covered by pension plans to invest $\$ 1,500$ each year tax-free, providing the money was not withdrawn before retirement age. Our planned Individual Saving Account (ISAs) would have some elements in common with this general idea, in that they would encourage savings, but the scope 
would be much more broad-based. Each taxpaying unit could treat up to $\$ 1,500$ per year in interest income, dividend income, or capital gains rollover as tax-exempt income. Thus, for example, if an individual had a savings account of $\$ 10,000$ on which he earned an average interest rate of $9 \%$ and dividend income of $\$ 1,000$, $\$ 1,500$ of that $\$ 1,900$ income would not be included in his gross taxable income. The plan would have certain strictures; taxpayers would have to keep their principal fully invested, although they could switch assets just as is the case for IRAs now. Any capital gains would have to be reinvested (rolled over) into other similar investments in order for that part of the exemption to qualify. However, the basic idea of an ISA would be that income generated from stocks, bonds, savings accounts, money market funds, or similar assets would be tax exempt as long as the principal remained invested in this class of assets. We estimate that this would cost about $\$ 6$ billion per year in ex ante revenue loss.

Clearly the establishment of ISAs would have many advantages. It would reduce the tax burden for savers, particularly smaller savers, and thus would be politically as well as economically popular with the vast majority of voters. It would stimulate savings and investment, and would pull the U.S. closer to being able to compete with other major industrialized nations in terms of gains in investment and productivity.

The disadvantages which ate likely to be raised are threefold. First, such a move would definitely increase the size of the federal budget deficit; no backward-bending supply curves would operate here. Second, it could be argued that most of the tax break would simply go to taxpayers who would save and invest in any case; i.e., it would attract very little new savings. Third, someone is sure to complain that most of the tax breaks will go to the "rich", which to a certain extent cannot be refuted because most of the poor don't save.

These objections suggest an alternative plan which would affect marginal savings more directly. Under this alternative, taxpayers would not receive an exemption or credit unless their savings in any given year were greater than the average savings rate for that income bracket. For example, if the average savings rate was $5 \%$ for a $\$ 30,000$ per year income, taxpayers at that level would not receive any exemption unless they saved over $\$ 1,500$ in that year. It is difficult to estimate the ex ante revenue loss, but it would certainly be under $\$ 5$ billion per year.

A third alternative plan would be to "start the tax table over" 
for nonwage income. For example, if a taxpayer had $\$ 50,000$ in wages and salaries and $\$ 10,000$ in interest and dividend income, the nonwage income would be taxed at marginal rates applying to $\$ 10,000$ of income, rather than $\$ 60,000$. Thus if a wealthy individual had, say, $\$ 250,000$ of interest and dividend income he would still pay high marginal tax rates-although in this case the top marginal bracket would be limited to $50 \%$, just as it is for wage income, rather than the current top level of $70 \%$. Indeed, we estimate that lowering the top tax bracket from $70 \%$ to $50 \%$ would actually net the Treasury about $\$ 3$ billion per year as taxpayers would shift out of tax-sheltered or tax-exempt sources of income.

Other alternative plans are available as well. The original concept of the IRA could be expanded to allow much more of a deduction than $\$ 1,500$. The principal and interest on money put aside to buy a home could be declared tax-exempt. In any case, all these schemes would have the net effect of reducing the net tax rate on saving. In the model we have assumed that some combination of these reductions would result in lowering the marginal tax rate on savings from its current level of $40 \%$ to $30 \%$, which would result in a net loss of revenue to the Treasury of $\$ 8$ billion per year before reflows.

As a result of these findings, we have also introduced some personal income tax cuts in the high-growth simulations, and some personal tax increases - mainly through bracket creep rather than actual rate hikes-in the low-growth simulation. While the changes in laws affecting investment behavior are the most important movers of the differential rate of growth, we should not ignore the effect of changes in personal income tax rates on labor force participation, the amount of labor offered by those already in the labor force, the level of productivity, and the increase in wage rates. We now examine these relationships in greater detail.

\section{RELATIONSHIP BETWEEN LABOR AND TAX RATES}

The theoretical literature of microeconomics has always posited significant relationships between the demand and supply of labor and the cost of that labor, including tax rates. A tax on labor (such as a social security tax) would raise the cost of this labor, thereby reducing its use. Similarly, an increase in taxes would reduce the supply of labor offered, although this effect is sometimes thought to be offset by the so-called backward bending supply curve. However, these linkages have been almost entirely absent from previous macroeconomic models, even though microeconomic studies, including several funded by the federal 
government, have shown significant elasticities for various classifications of employees, particularly secondary workers in the labor force.

In addition to the beneficial aspects of tax cuts on saving and investment in our new macroeconomic model, we have also found significant relationships between changes in personal income taxes and labor market conditions. These can be subdivided into three areas: labor force participation, amount and quality of work offered, and increase in wage rates.

Typical macroeconomic labor supply functions have been estimated in the form of labor force participation rates by demographic composition, with the principal independent variable being the lagged value of the unemployment rate. Both theory and microeconomic results suggest that the real wage should be included as an additional determinant of labor force participation. However, on an empirical basis the problem of separating out the income and substitution effects has proved baffling. In general we would expect that an increase in the wage rate would have offsetting effects. The higher wage would induce an increase in labor supply, following the usual upward-sloping supply curve for factors of production. However, an increase in income would result in substitution of leisure for work, following the so-called backward-bending supply curve. Furthermore, an increase in prices generally reduces the real income of the wage earner, so that a higher rate of inflation would draw more people into the labor force in an attempt to make ends meet.

The major problem in estimating labor force participation rate equations with the wage rate has always been the difficulty in sorting out the difference between the substitution and income effects, since they should have different signs. Furthermore, most of the theoretical work has been done under assumptions which assume constant prices, whereas in reality fluctuations in the real wage due to inflation are among the major determinants of labor force participation.

Let us first turn to the problem of the income and substitution effects. Musgrave has suggested that this problem can be handled by considering the average and the marginal tax rates separately. He argues that work effort will decline if the marginal rate is raised (substitution effect) but will increase if the average rate is raised (income effect). From a theoretical point of view, therefore, the problem is solved by entering both of these tax rates.

From an empirical point of view, however, it is perfectly obvious 
that these rates move together over time, and that it is not possible to measure the empirical effects separately on a time-series basis. One way around this problem is to introduce an income term together with the marginal tax rate in the labor force participation rate equations. Thus we have included the wage bill deflated by the CPI, thus incorporating elements of both the wage rate and income. While not a perfect solution, this combined variable does enable us to estimate more robust estimates of the effect of tax rates on labor force participation, separate the average and marginal tax rate effects, and include the theoretical desirable income term.

Thus the key variable used in the labor force participation rate equation is:

$$
\frac{W}{C P I}\left(1-t_{m}\right)
$$

where: $W=$ wage and salaries;

CPI = consumer price index; and

$\mathrm{t}_{\mathrm{m}}=$ marginal tax rate as calculated by Evans Economics, Inc. (EEI).

We now turn to the distinction between primary and secondary workers in the labor force. In general economists have found a modest if not insignificant relationship between labor force participation rates for males aged 25 to 54 and either the real wage or the rate of inflation. On the other hand, we would expect both of these variables to be quite significant for secondary workers in the labor force.

We also need to consider the effect of changes in the marginal tax rate on labor supply. Again one can raise the question of whether the substitution or income effect dominates; as tax rates rise, it could be argued, labor supply increases in order to hold real income constant. However, the overwhelming evidence of the microeconomic studies suggest that the substitution effect predominates, and that an increase in tax rates reduces the supply of labor offered. Thus we have combined the tax term with the real wage term in all of these equations.

We thus expect the standardized labor force participation rate equation to contain the following terms: the unemployment rate, the wage bill divided by the price level, the marginal tax rate on personal income, and the rate of inflation.

It is often claimed that the minimum wage has contributed to an 
increase in the unemployment rate among teenagers, since they are the potential employees whose marginal product is most likely to be lower than the minimum wage. While this is undoubtedly the case, the relationship has another dimension, which is that the existence of the minimum wage barrier also deters many teenagers from entering the labor force in the first place. Thus we find a significant negative correlation between labor force participation rates for those aged 16 to 24 and the minimum wage in real terms. A $1 \%$ increase in the minimum wage will reduce labor force participation by approximately $0.2 \%$.

At the other end of the age spectrum, we find a very strong negative correlation between social security benefits in real terms and labor force participation for those 55 and older. Since the benefits are tied to the cost-of-living and in fact are one of the very few types of personal income to outstrip inflation over the past decade, it is clear that an increase in the rate of inflation raises real income for recipients, especially when it is considered that social security benefits are tax-free whereas earned income is subject to personal and social security taxes. Hence the situation for retirement-age individuals is unlike the situation for the rest of the work force, for whom an increase in inflation lowers real income and thus leads to greater labor force participation. One might argue that real income remains constant for those on social security, but actually very few people over 55 are buying or financing new homes, and hence the CPI increase clearly overstates the increase in their cost of living. Also, those over 65 receive medical care free of charge; hence those rapidly rising prices are also not indicative of the costs faced by older citizens.

The empirical results for labor force participation are best divided into primary and secondary members of the work force. The effects on primary workers, defined here as males aged 25 to 54 , are significant but small. A one percentage point (p.p.) reduction in the marginal personal income tax rate would result in only a $0.05 \%$ increase in the primary labor force. However, it would result in a $0.37 \%$ increase in the secondary labor force. However, total increase in the labor force caused by a 1 p.p. reduction in the tax rate would be $0.26 \%$, or approximately 270,000 workers at the present size of the labor force.

The labor force participation equations also indicate that a $1 \%$ increase in the real minimum wage (adjusted for inflation) would decrease labor force participation for those aged 16 to 24 by $0.2 \%$. At the other end of the age scale, a $1 \%$ increase in real per capital 
social security benefits would diminish labor force participation of those 55 and over by $0,4 \%$.

The equations relating the amount of utilized labor to output, capital stock, and productivity are usually known as inverted production functions or labor demand functions. However, they are actually a reduced form of labor demand and supply equations, since the amount of labor used depends both on the demand for labor by business and the degree of willingness to offer their labor.

These combined effects are very significant. We find that a $1 \%$ increase in the average personal income tax rate including social security taxes will reduce the amount of labor utilized by $0.5 \%$. This decline is caused by several factors. First, an increase in the cost of labor through higher social security taxes will reduce the demand. Second, an increase in tax rates will reduce hours worked per week; we find that this effect accounts for slightly over half of the total reduction in labor offered. Third, higher taxes lead to a rise in vacation time, absenteeism, and unwillingness even to work at all by some members of the labor force.

The results we have found on the effect of changes in taxes on work effort are quite striking. Yet they are corroborated by some cross-section studies which we performed for the years 1962 and 1966. These years were chosen because they bracketed the major 1964 tax cut. We used the IRS tapes and stratified the income tax returns by income classification in order to determine what happened to work effort when taxes were reduced.

Basically the approach we have taken is the following. We know that tax rates were reduced significantly between 1962 and 1966. For any given level of adjusted gross income (AGI), we examined what happened to the proportion of income accounted for by the sum of wages and salaries and business and professional incomein other words, income earned from current work effort. If this proportion remained unchanged we could conclude that the reduction in tax rates had no significant influence on work effort. If it increased, however, we could conclude that the tax reduction heightened work effort. Note that by holding AGI constant in the regressions we have automatically excluded any increase in work effort which might have accrued from the overall growth in the economy or rise in productivity. Our analysis is strictly a marginal one for any given level of income.

We found the following results for a $1 \%$ reduction in tax rates. For lower-income workers, such a reduction would raise work effort by about $0.1 \%$. For middle and upper-middle workers, the 
increase was about $0.25 \%$. For upper-income workers-those with taxable income of $\$ 120,000$ or more - we found that elasticities were in excess of 2.0 . The upper-income elasticities are probably overstated for the following reason. When the top marginal tax rate dropped from $91 \%$ to $70 \%$, many individuals simply shifted some of their compensation from capital gains and stock options back into earned income. As a result, tax revenues in the top bracket more than doubled from 1964 to 1966 after accounting for growth in the economy even though the top bracket rates dropped drastically.

We now consider the wage rate functions in the supply-side model, for they play a critical role in determining the rate of inflation. From the point of view of supply-side economics, the view that we cannot simultaneously have full employment and stable prices is anathema, for it is just this combination which our model shows how to achieve. The problem is that a decline in unemployment is usually triggered by policies which increase aggregate demand but do not raise aggregate supply. When this happens, it is small wonder that inflation eventually rises. However, balanced growth policies, which raise both demand and supply at the same rate, will lead to lower unemployment without increasing inflation.

Yet if we accept the empirical proposition that a strong negative relationship exists between wages and unemploynent, how can we then claim that a decline in unemployment will not result in higher wages, unit Jabor costs, and prices?

Several possibilities can be considered. The main ones are as follows:

1. The decline in unemployment is accompanied by an increase in productivity, thus offsetting higher wage rates. This would occur, for example, if the reduction in unemployment were due to greater capital spending.

2. The decline in unemployment is accompanied by a reduction in personal income tax rates, thereby causing wage earners to accept smaller pre-tax pay increases.

3. The increase in output is accomplished by increasing labor force participation and lengthening the work week, thereby leaving the unemployment rate almost unchanged. This solution is preferable mainly when the economy is near full employment; but as indicated in our previous discussion, that is when the trade-off between wages and unemployment becomes most severe. When slack still exists in the labor markets, the increase in wage rates 
stemming from a decline in unemployment is much smaller.

4. An increase in output could be accompanied by declining prices for other factors, such as an improvement in the value of the dollar and hence lower import prices.

To be sure, these changes will not happen automatically. In fact, it is probably the rule rather than the exception that wages, unit labor costs, and prices will rise as unemployment falls. However, to state that this is a general empirical rule because of past experience does not necessarily imply that policies which will of fset or mitigate this trade off cannot be fashioned. In fact, we have just proposed four solutions which would accomplish just that.

It should be stressed that the lags on all of these variables are substantial. The unemployment rate is included with an average lag over the past two years. The lag on the CPI is at least one year in all cases and ranges as far back as three years in the construction equation. Similarly, the personal tax rate is averaged over the past two to three years. Thus the effects which we are describing clearly do not happen instantaneously. They do, however, point out that delayed wage demands may be viewed as somewhat of a "ticking time bomb" in the aftermath of sharp increases in inflation or tax rates. Just because wage demands do not spiral up immediately after inflation and taxes increase does not necessarily mean that they will never catch up, for the lag process can take up to three years to become fully effective.

The generalized wage rate function which we estimate is of the form:

$$
\frac{w-\vec{w}}{\bar{w}}=a_{0}+a_{1} g(U n)+a_{2} \frac{p-\vec{p}}{\bar{p}}+a_{3} t_{p}
$$

where: $w=$ average wage rate;

Un = unemployment rate;

$\mathrm{p}=$ consumer price index;

$t_{p}=$ average tax rate on personal income;

$$
\begin{aligned}
& \overline{\mathrm{x}}=\mathrm{y}_{\mathrm{i}=1}^{4 / 4} \mathrm{X}_{-\mathrm{i}} ; \text { and } \\
& \mathrm{g}=\text { a generalized nonlinear function, e.g., } \frac{1}{\mathrm{Un}}
\end{aligned}
$$

Both the unemployment and inflation terms are in common use in macroeconomic wage rate equations. However, the last major tem which we use in these equations, namely the average tax rate on personal income, definitely is not. Yet its inclusion should not 
be considered particularly surprising. An increase in tax rates will cause workers to bargain for wage increases in excess of the rise in inflation in order to keep their real income constant. Similarly, a tax reduction will permit them to accept gains which are less than the rate of inflation because their take-home pay will still be at the same or higher levels.

The elasticities for the various sectors of the economy, and for total private nonfarm business, are given in Table 4 . We see that a $1 \%$ increase in the CPI eventually results in a $0.62 \%$, or $5 / 8 \%$, rise in wage rates. While this figure is high, it is not unity. Even after a lag of up to three years, wage earners do not recoup the full increase in the reported CPI. This fact has been fairly evident ever since 1973 , when the real wage was some $10 \%$ higher than current levels in spite of two tax cuts in the intervening years.

\section{TABLE 4}

\section{Elasticities for Wage Rate Equations}

\begin{tabular}{|c|c|c|c|c|}
\hline & $\begin{array}{c}1 \% \text { Change } \\
\text { in CPI }\end{array}$ & $\begin{array}{l}\text { 1 } \% \text { Change } \\
\text { in Un }\end{array}$ & $\begin{array}{l}{ }^{5} 1 \% \text { Change } \\
\text { in Un } \\
\end{array}$ & $\begin{array}{l}\text { el\% Change } \\
\text { in } t_{p}\end{array}$ \\
\hline Manufacturing & 0.58 & 0.25 & 0.82 & 0.50 \\
\hline Construction & 0.87 & 0.67 & 2.23 & 0.46 \\
\hline Nonmanufacturing & 0.62 & 0.00 & 1.17 & 0.37 \\
\hline $\begin{array}{l}\text { Total private } \\
\text { nonfarm }\end{array}$ & 0.62 & 0.11 & 1.13 & 0.41 \\
\hline
\end{tabular}

The elasticity with respect to unemployment is nonlinear, as we think it should be. Above $8 \%$ unemployment we do not find any effect at all on wage rates from a change in unemployment. The change in each percentage point below $8 \%$ then becomes progressively larger. We have selected two points on this unemployment/wage trade-off curve: a change from $8 \%$ to $7 \%$, and a change from $5 \%$ to $4 \%$. As can be seen, a change in the first case results in a change in wage rates well below $1 \%$, whereas a change in the second case results in a change in wage rates somewhat above $1 \%$.

We finally turn to the change in wage rates resulting from a change in the average tax rate. It is encouraging to find that the coefficients in all of the three equations are bunched closely 
together. While we might expect differences in the unemployment/ wage rate trade-off in different industries because of varying institutional and union structure, we would expect that workers would respond similarly to changes in tax rates regardless of the particular industry in which they were employed. We find that for the overall economy, a 1 p.p. change in tax rates (i.e., from $30 \%$ to $31 \%$ ) would result in a $0.4 \%$ change in wage rates. However, this is only an impact multiplier although it does take place over as much as three years; we also need to consider the total effect after including the interaction between wages and prices.

In order to understand the dynamics of the wage-price-tax interaction, let us aggregate the equations in the wage sector. We then find that a 1 p.p. reduction in personal income tax rates will reduce prices by about $0.45 \%$ and wage rates by about $0.70 \%$. Since wage rates rise a full $1 \%$ because of lower taxes, the after-tax increase in the real wage rate stemming from the tax reduction is $0.9 \%$.

To summarize the results of this section, we find that:

1. A 1 p.p. change in the tax rate will change labor force participation in the opposite direction for primary workers by a minuscule $0.05 \%$ but will change the participation rate for secondary workers by $0.37 \%$.

2. A 1 p.p. change in the tax rate will change employment-hours in the opposite direction by $0.5 \%$. Much of this change stems from the change in hours worked.

3. A 1 p.p. change in the tax rate will change the average wage rate in the same direction by $0.4 \%$ on impact, and $0.7 \%$ when the interaction between prices and wages is considered.

Thus a reduction in the personal income tax rate would increase the supply of labor, increase the number of hours worked, and reduce the gain in average wage rate. An increase in the demand and supply of labor would expand the maximum productive capacity of the economy. Thus inflation would be reduced both through a lower wage rate and a higher level of maximum capacity, thus widening the gap between actual and maximum capacity.

\section{MAfor Linkages IN THE SUPPly-Side Model}

One of the reasons that demand-oriented policies have been used almost exclusively in the past 15 years is that all of the current large scale econometric models have indicated that these policies will benefit the economy more than supply-side changes. Embedded in 
these models is the implicit assumption that an increase in demand will automatically trickle down to increase aggregate supply, thus insuring balanced, noninflationary growth.

However, there is nothing magical about the balance between aggregate demand and supply. If incentives are lacking for investment, capital formation will stagnate. If incentives are lacking for labor, labor force participation will decline, the amount of labor offered by those already in the labor force will be reduced, and productivity will diminish. As a result, total productive capacity of the economy will grow more slowly than total demand, and bottlenecks, shortages and higher inflation will eventually result.

According to Keynesian demand economics, this higher inflation must then be fought by causing a recession and reducing aggregate demand. It is true that the gap between aggregate demand and supply must be widened in order to diminish inflationary pressures. However, surely there are two ways to accomplish this aim. One is indeed to diminish demand, thereby causing higher unemployment. The other is to increase aggregate supply, thereby raising the production possibility curve of the economy and increasing jobs and output at the same time that inflation is being lowered. This is the fundamental hypothesis underlying our supply-side modeling.

As already noted, most fiscal policy analysis of the past 15 years has been based on the belief that an increase in government spending will lead to a larger rise in demand and output than an equivalent reduction in taxes. The reasoning which leads to this conclusion is straightforward if inaccurate. If the government increases its spending, the entire dollar is used to raise aggregate demand. If taxes are cut, however, some of each dollar is used for saving. Since existing Keynesian models do not incorporate the links between saving and investment, demand does not rise as much.

Furthermore, these models also state that a personal income tax cut has a larger effect than a corporate income tax cut, and for much the same reason. Individuals spend a larger proportion of the extra money they receive from reduced taxes than do corporations, and that left-over saving does not contribute to economic growth or prosperity.

The supplywside model which we have built gives exactly the opposite result: an income tax cut has a larger effect on the economy than an increase in government spending. The supply-side mechanisms which support this conclusion can be qualitatively summarized as follows. In particular, a reduction in personal and 
corporate income taxes will set in motion the following chain of events.

1. An increase in the after-tax rate of return on personal saving occasioned by a reduction in personal income tax rates raises the incentives of individuals to save. This increase in saving leads to lower interest rates and higher investment.

2. A reduction in the effective corporate income tax rate, either through lower tax rates, a higher investment tax credit, or more liberal depreciation allowances, improves capital spending directly by increasing the average rate of return.

3. An increase in both personal and corporate saving leads to greater liquidity and less loan demand, thereby lowering interest rates. These effects help both capital spending and residential investment.

4. A rise in the ratio of investment to GNP leads to higher productivity, which means that more goods and services can be produced per unit of input. As a result, unit costs do not rise as fast and inflation grows more slowly.

5. A reduction in personal income tax rates leads to a rise in labor force participation and work effort, thereby increasing the supply of labor necessary to produce more goods and services.

6. Thus labor supply, capital stock, and productivity are alt increased by lower tax rates, thereby expanding the maximum productive capacity of the U.S. economy.

7. As a result of higher maximum capacity the inflationary pressures of shortages and bottlenecks diminish, thereby reducing the rate of inflation.

8. An increase in maximum capacity also permits the production of more goods and services for export markets. This improves our net foreign balance and strengthens the dollar, thus leading to lower inflation because imported goods decline rather than advance in price.

9. Lower personal income tax rates lead to smaller wage gains, since wage bargaining is based at least in part on the level of after-tax income. This in turn reduces inflation further.

10. Thus lower tax rates cause a reduction in inflation through several channels. Inflationary pressures decline as the gap between actual and maximum potential GNP rises; productivity increases, thereby lowering unit labor costs; the dollar strengthens, causing less imported inflation; and wage rates rise more slowly.

11. Lower inflation leads to higher real disposable income, since 
bracket inflation is mitigated. The rise in income leads to an increase in consumption, output, and employment.

12. Lower inflation leads to lower interest rates, stimulating investment in both plant and equipment and in housing.

13. The increased demand for goods and services stemming from lower inflation is matched by the rise in the maximum potential capacity of the economy to produce these goods and services, thereby resulting in balanced, noninflationary growth.

One of the most important sets of linkages in the supply-side model is the relationship between saving and investment. For if saving rises and these funds are just used to increase idle cash balances, investment may not expand. However, these links are well documented in our model.

A $\$ 10$ bilition increase in personal saving raises time deposits by $\$ 3.0$ billion and thrift institution deposits by $\$ 1.6$ billion. In addition, it reduces loan demand by $\$ 3.6$ billion.

As a result of these changes in the balance sheet of commercial banks, demand for U.S. government securities by the banks increases by $\$ 11.5$ billion. This results in approximately a $10 \%$ decline in interest rates and a $3.2 \%$ increase in stock market prices.

These changes have two related effects on investment. First, lower interest rates and higher stock prices stimulate fixed business investment. Second, easier credit increases housing starts and mobile homes and, to a lesser extent, producers durable equipment.

As would be expected, nonresidential construction is more sensitive to changes in interest rates and stock prices than is equipment. Thus we find a $\$ 2.5$ billion increase in structures, as compared to a $\$ 1.3$ billion rise in producers durable equipment from a $\$ 10$ billion increase in personal saving. Residential construction rises $\$ 1.5$ billion because of credit easing and $\$ 1.2$ billion because of lower interest rates. These are, of course, only first-round effects which do not take into account the increase in investment stemming from higher income and output. However, these results do document the strong linkages between saving and investment which exist in the supply-side model. For if these linkages are not strong, the second-round effects will not be observable either.

Another important breakthrough in our supply-side model is the endogenous explanation of productivity, which we have atready discussed in the first section.

A $10 / 2$ increase in productivity will not only expand maximum 
potential GNP by that amount; it will initially lower prices by $2 / 3 \%$, since labor costs consist of $2 / 3$ of total factor costs. This is only the first-round effect, since lower prices will lead to tower wages and further declines in unit labor costs and prices. The total effect of a $1 \%$ increase in productivity is to reduce prices by about $2 \%$.

We are also able to introduce other innovations into the supplyside model because of the endogenous treatment of maximum capacity. In particular, the model introduces the concept of the cumulative gap, already discussed in the first section, which we define as the cumulative difference between $99 \%$ of maximum GNP and the actual level of GNP when this gap is negative. When it is positive-i.e., actual GNP is below maximum potential output inflationary pressures do not build because of bottlenecks and shortages. However, when it is negative, prices start to rise faster than would be indicated by the cost of factor inputs alone.

So far this term does not sound greatly different than an index of capacity utilization, although it is much more inclusive in that it covers all sectors of the economy. However, we have cumulated this gap for all periods when the gap is negative. This term therefore indicates that inflationary pressures build up over many years and do not disappear every time a mild recession occurs. The inefficiencies and distortions which occur when the economy is operating near full capacity are not reversed overnight, and remain as a legacy until the cumulative gap once again returns to zero. This term may also represent the gradual buildup of inflationary expectations.

The final area of the model in which supply-side economics has been incorporated is the integration of the international sector with the U.S. economy. Again, this is an area where theoretical economists have long posited strong links, but they have never been empirically documented within the context of a macroeconomic model.

Supply-side effects are important in two specific areas. First, an increase in the gap between actual and maximum potential GNP raises exports, since the greater capacity of the U.S. economy permits the production of more goods and services for export markets as well. A $1 \%$ increase in this gap raises net exports by about $\$ 0.7$ billion per year; since the gap is cumulative, this figure continues to increase linearly and is, for example, $\$ 2.1$ billion after three years.

The second major effect is the link between the trade-weighted 
average of the dollar, which is itself closely tied to the size of the net foreign balance, and the overall rate of inflation. We find that a $10 \%$ decline in the value of the dollar relative to a trade-weighted average of the Deutschemark, French franc, Belgian franc, Dutch guilder, and Japanese yen raises the producer price index $1.3 \%$ and the consumer price index about half that much after a period of two years.

Thus we can document several supply-side relationships that have a significant effect on inflation as well as the rate of growth. All these figures refer to the change in the CPI and are impact estimates only. First, a 1 p.p. decline in the personal income tax rate will lower wage rates and thus prices by about $0.5 \%$. Second, a $1 \%$ increase in productivity will lower prices by $2 / 3 \%$. Third, a $10 \%$ improvement in the trade-weighted average of the dollar will reduce inflation by about $0.6 \%$. Fourth, after a three-year period, a $1 \%$ increase in the gap between actual and maximum GNP will lower prices by $0.4 \%$. It is worth repeating that all of these figures are impact estimates only and do not take into account the interaction between wages, prices, productivity, and other factors of production. Indeed, the final changes in prices are between two and three times the initial impacts, depending on cyclical conditions at the time.

Thus we find that the nemesis of demand-side economics, namely that output must be reduced and unemployment increased in order to dampen the rate of inflation, is only one of several alternatives. Inflation can also be reduced by increasing productivity, reducing personal and corporate tax rates, and strengthening the value of the dollar. We would not quarrel with the statement that the size of the gap between actual and maximum potential GNP is one of the factors determining the rate of inflation, but do believe that other factors must be considered as well.

The actual reduction in the implicit GNP deflator for the highgrowth, high-deficit case is only $1.3 \%$ by 1990 , although even this represents a marked change from the usual finding that inflation would be higher. The two principal reasons for this discrepancy are a) the lag structure and b) the large deficit. The changes in productivity do not immediately translate into lower prices, since both changes in wages and prices react to change in economic stimuli with a substantial lag. In addition, the benefits to higher productivity from higher investment are not felt immediately.

The second and more important reason is that the huge budget deficit pushes up interest rates, thereby contributing to higher costs 
of doing business and also raising the CPI through higher mortgage interest rates.

Because of the fact that the implicit GNP deflator declines in this high growth scenario, we find that the reflows are rather modest. Hence the ex post deficit in 1990 is approximately $\$ 500$ billion in spite of the higher growth generated. While such a deficit is economically feasible because the dissaving by the government is funnelled into saving by the private sector, we do not think it would be politically feasible, nor do we consider it the optimal solution.

For this reason we have calculated another high-growth scenario, one with a balanced budget, which is generated by reducing transfer payments. This alternative high-growth scenario, which we then adopt as our preferred run, also provides additional information about the timing and magnitude of government spending multipliers.

\section{GENERATING A HIGH-GROWTH SCENARIO: THE BALANCED BUDGET CASE}

To generate this simulation, we made only one change from the previous high-growth run: we reduced transfer payments enough to generate a balanced budget. This resulted in transfer payments increasing only $2.2 \%$ per year (current dollars) instead of the $11.4 \%$ per year increase which is included in both the baseline and high growth-large deficit scenario. The total reduction in transfer payments by 1990 is approximately $\$ 500$ billion per year.

Before examining the economic ramifications of such a reduction, it certainly is worth asking whether it would be possible to cut transfer payments by this amount while still tetaining the present social fabric of the United States. Figures on the projected growth of transfer payments over the next decade under alternative assumptions are given in Table 5.

For purpose of this analysis, we can divide transfer payments into three categories: retirement benefits, medical care payments, and other transfers, which are largely veterans benefits and welfare payments. Under the baseline case, retirement benefits are expected to grow at a rate equal to the annual average increase in the CPI plus the average increase in the population over 65. A similar formula would apply for medical care benefits, although there we use the increase in the $\mathrm{CPl}$ for medical care. Other transfer payments are expected to grow at a rate of increase equal to the 
TABLE 5

Projected Growth of Transfer Payments

\begin{tabular}{|c|c|c|c|c|c|c|}
\hline & \multicolumn{3}{|c|}{ Annual Increase Due To: } & \multirow{2}{*}{$\begin{array}{c}\text { Total } \\
\text { Annual } \\
\text { Change }\end{array}$} & \multirow[b]{2}{*}{$\begin{array}{c}1990 \\
\text { (billions }\end{array}$} \\
\hline & & Inflation & Pop. & $\begin{array}{l}\text { Change in } \\
\text { Coverage }\end{array}$ & & \\
\hline \multicolumn{7}{|c|}{ A. Baseline } \\
\hline Retirement Benefits & $\$ 157$ & $9.9 \%$ & $2.0 \%$ & $0.0 \%$ & $12.1 \%$ & $\$ 490$ \\
\hline Medical Care & 38 & 10.1 & 2.0 & 1.0 & 13.4 & 134 \\
\hline Other & 98 & 8.3 & 1.0 & 0.0 & 9.4 & 241 \\
\hline TOTAL & 293 & & & & 11.4 & 865 \\
\hline \multicolumn{7}{|c|}{ B. Adjustment for Lower Inflation Only } \\
\hline Retirement Benefits & $\$ 157$ & $6.1 \%$ & $2.0 \%$ & $0.0 \%$ & $8.20 \%$ & $\$ 344$ \\
\hline Medical Care & 38 & 7.8 & 2.0 & 1.0 & 11.0 & 108 \\
\hline Other & 98 & 7.5 & 1.0 & 0.0 & 8.5 & 222 \\
\hline TOTAL & 293 & & & & 8.7 & 674 \\
\hline
\end{tabular}

C. Lower Inflation and Cutbacks in Program

$\begin{array}{lllllll}\text { Retirement Benefits } \$ 157 & 6.3 \% & 2.0 \% & -9.0 \% & -0.7 \% & \$ 147\end{array}$

$\begin{array}{lllllll}\text { Medical Care } & 38 & 7.8 & 2.0 & -5.0 & 5.0 & 62\end{array}$

$\begin{array}{lllllll}\text { Other } & 98 & 7.5 & 1.0 & -3.7 & 4.6 & 154\end{array}$

$\begin{array}{llll}\text { TOTAL } & 293 & 2.2 & 363\end{array}$

amplicit Constant Deflator instead of CPI 
average rise in the implicit GNP deflator plus the average gain in total population. These figures are all given in Table 5A.

The figures in Table 5B are adjusted for lower inflation, and also incorporate the assumption that retirement benefits would be indexed to the implicit deflator for consumption rather than the CPI, since the tendency of the latter to overstate price increases because of its overdependence on the cost of buying and financing a home is now well known. Thus switching to the higher-growth lower-inflation scenario, plus this one sensible adjustment it the indexation scheme for social security benefits, reduces transfer payments by almost $\$ 200$ billion per year by 1990 .

While this $\$ 200$ billion is indeed an impressive saving, it is far less than the $\$ 500$ billion which is needed to balance the budget. Table $5 \mathrm{C}$ provides the arithmetic to indicate how these remaining savings are achieved. From an economic point of view, the following changes are instituted:

1. The retirement age is raised from 65 to 70 . There is nothing sacrosanct about the number 65 for a retirement age; indeed, if we use the most recent actuarial tables, we find that a retirement age of 65 in the mid 1930 s (when social security was originally implemented) now corresponds to an age of almost 70 , and that figure will probably rise to 72 by the end of this decade.

As might be expected, the savings in postponing the retirement age are substantial. Each additional year of postponement-e.g., from 65 to 66 -saves the government $\$ 18$ billion at current levels of benefits and poplation. If we adjust this figure upward for the increase in the implicit consumption deflator and the growth in population over 65 , by 1990 this figure amounts to $\$ 40$ billion for each year the retirement age is postponed. Thus raising the retirement age to 70 would save a whopping $\$ 200$ billion, in which case retirement benefits would actually be somewhat below present levels.

The other cuts are less drastic. The reduction in medical care benefits could be accomplished, we believe, by simply adding a deductible and coinsurance whereby the patient would pay the first $\$ 100$ per year of medical expenses and $90 \%$ of the remainder up to some fixed linit which might be equal to, say, $10 \%$ of his annual income. For example, if an individual had an income of $\$ 20,000$, he would be required to pay no more than $\$ 2,000$ in medical premiums that year regardless of the extent of his actual bills. This would provide $100 \%$ coverage for catastrophic illness while alerting patients to the substantial cost of medical services which is borne 
by society at large. We estimate that the deductible and coinsurance as outlined above would cut the growth of medical care payments in half.

The remaining cuts would occur in the phasing back of existing programs, such as food stamps for college students, a cap on black lung payments, reduction in the Aid to Families with Dependent Children as these parents returned to work, and other similar welfare programs. Of the three major areas, these cuts are proportionately the smallest and the most politically feasible.

It should be made quite clear that workers who no longer receive retirement benefits at ages 65 through 69 will remain in the labor force, but the higher growth rates will certainly provide the additional jobs necessary to support these older workers. As we have already mentioned above, the U.S. economy will shift from a labor surplus to a labor shortage economy by 1990 , and the jobs which these older workers retain will mitigate the labor shortage problem. Hence the gradual raising of the retirement ageincreasing it, for example, six months every year over the next. decade-would fit hand in glove with the need for more workers and the redirection of resources from the public to the private sector.

\section{COMPARISON OF THE TWO HIGH-GROWTH SCENARIOS}

Based on traditional multiplier analysis, one might expect that the $\$ 500$ billion decrease in transfer payments would result in a far slower rate of growth because of the resulting decline in consumption. However, this is not at all what happens. The reduction in the federal government budget deficit lowers interest rates, thereby stimulating capital formation. Furthermore, the lower rate of inflation which stems from higher productivity growth also reduces interest rates. Finally, since income is redistributed to those who are working away from those who are not, labor force participation rises, which provides the additional labor inputs needed to complement increased capital spending.

The comparison for several key variables is given in Table 6. In particular we note that while real growth is about $1 / 2 \%$ per year higher for the largest deficit case in the early $1980 \mathrm{~s}$, the pattern is completely reversed in the second half of the decade, and by 1990 real GNP is increasing almost $1 / 2 \%$ per year faster for the balanced budget case. As can be seen, the rate of inflation is approximately $1 \%$ per year lower for the balanced budget case after 1985 . 
$74 /$ SUPPLY-SIDE ECONOMETRIC MODEL.

TABLE 6

Comparison of Two High-Growth Scenarios

$1981 \quad 1982 \quad 1983 \quad 1984 \underline{1985} 1986 \quad 1987 \quad 1988 \quad \underline{1989} 1990$

Real GNP, \% Growth

$\begin{array}{lllllllllll}\text { Large deficit } & 2.6 & 6.2 & 4.4 & 1.0 & 2.1 & 3.4 & 3.9 & 4.4 & 4.8 & 5.0\end{array}$

$\begin{array}{lllllllllll}\text { No deficit } & 2.5 & 5.9 & 3.8 & 0.2 & 1.6 & 3.2 & 4.1 & 4.7 & 5.2 & 5.4\end{array}$

Implicit GNP Deflator, \% Growth

$\begin{array}{lllllllllll}\text { Large deficit } & 9.2 & 8.7 & 8.8 & 8.6 & 7.6 & 6.6 & 6.1 & 5.6 & 5.3 & 4.9\end{array}$

$\begin{array}{lllllllllll}\text { No deficit } & 9.2 & 8.7 & 8.6 & 8.2 & 6.9 & 5.7 & 5.0 & 4.5 & 4.2 & 3.8\end{array}$

Federal Budget Surplus or Deficit, billions of $\$$

$\begin{array}{lllllllllll}\text { Large deficit } & -78 & -70 & -92 & -148 & -199 & -239 & -284 & -348 & -416 & -508\end{array}$

$\begin{array}{lllllllllll}\text { No deficit } & -65 & -19 & -2 & -15 & -16 & -2 & 13 & 15 & 16 & -4\end{array}$

Government Spending/GNP, ratio

$\begin{array}{lllllllllllll}\text { Large deficit } & 37.1 & 35.5 & 34.5 & 34.8 & 35.1 & 35.2 & 35.2 & 35.2 & 35.2 & 35.2\end{array}$

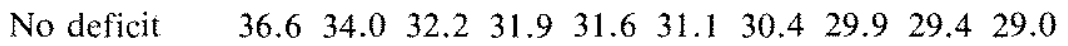

AA Utility Bond Rate, \%

$\begin{array}{lllllllllll}\text { Large deficit } & 11.5 & 11.3 & 11.7 & 13.0 & 13.6 & 14.1 & 14.6 & 15.5 & 16.6 & 18.0\end{array}$

$\begin{array}{lllllllllllll}\text { No deficit } \quad & 11.5 & 11.0 & 10.9 & 11.8 & 11.5 & 11.3 & 11.0 & 11.2 & 11.5 & 12.2\end{array}$

LOW GROWTH SCENARIO

We have generated a high-growth scenario with a balanced budget by cutting corporate and personal income tax rates dramatically and then balancing the budget through lower transfer payments. The low-growth alternative, however, cannot realistically be generated by raising tax rates the same amount they were cut in the high-growth alternative, for no one expects the statutory tax rates to be raised during the $1980 \mathrm{~s}$, although rates may drift up 
because of bracket creep. Thus we must lower growth directly by reducing growth in the labor force and by lowering the rate of growth in productivity. This can be done by a combination of a) higher tax rates through bracket creep, b) higher costs of government regulation, and c) higher relative energy prices.

Thus we have approached the low-growth scenario in a much different manner, and have changed those variables which impact directly on labor force growth and productivity other than income tax rates. The changes which we have introduced to generate this scenario are the following;

1. Energy prices, both imported and domestic, grow at a faster rate.

2. The cost of government regulation doubles over the decade.

3. Labor force participation rates grow more slowly.

4. Transfer payments grow $15.6 \%$ per year instead of $11.4 \%$. The average tax rate increases from $24.9 \%$ to $38.3 \%$ by 1990 - but that is entirely due to bracket creep and does not reflect any rise in the statutory rate.

In addition to these four changes, we have also cancelled any personal or corporate income tax cuts over the decade which are included in the baseline, held depreciable lives at 1980 levels, and terminated the investment tax credit. However, it should be stressed that these do not account for the bulk of the decline in growth which occurs in this scenario-that is due to the four factors listed above.

\section{COMPARISONS OF THE ALTERNATIVE SCENARIOS}

We now compare the performance of the economy, on a decadelong average and for year-by-year changes, for the baseline, high growth with balanced budget, and low-growth scenarios. We have not included the high growth with large deficit run, since that is not a feasible alternative; furthermore, we have already discussed the difference between the two high-growth runs in the previous subsection. The principal assumptions and results are presented in Table 7.

While the decade average figures are useful, they really do not convey the full flavor of the differences between the runs; this is best done by examining the differences in the forecast on an annual basis, which is presented in Table 8 . Here we note the great divergence which occurs in the saving rate, growth in productivity, and inflation, particularly after 1985 . The forecasts are somewhat 


\section{TABLE 7}

Growth Rates

(1980 - 1990)

Selected Economic Indicators for Alternative Scenarios

\begin{tabular}{lcccc} 
& Baseline & $\begin{array}{c}\text { High } \\
\text { Growth }\end{array}$ & $\begin{array}{c}\text { Low } \\
\text { Growth }\end{array}$ \\
\cline { 2 - 2 } \cline { 5 - 5 } Real GNP & 2.9 & & 3.6 & 1.6 \\
Labor Input & 2.0 & & 1.6 & 1.3 \\
Labor Productivity & 0.9 & & 2.0 & 0.3 \\
Labor Force Participation & 0.6 & & 0.8 & \\
Real GNP per capita & 2.0 & & 2.7 & 0.3 \\
Relative Price of Energy (PPI) & 6.6 & & 6.8 & 7.2 \\
Growth of Transfer Payments & 11.4 & & 2.1 & 15.6
\end{tabular}

Levels in 1985

Personal Income Tax Rate

Corporate Income Tax Rate

Investment Tax Credit

Depreciation Lives, Equipment

Depreciation Lives, Structures
0.227

0.168

0.284

0.46

$10 \%$

8.4

18.4
0.20

0.46

$10 \%$

$0 \%$

10.5

5.0

23.0

similar for the first five years but then differ markedly, which emphasizes the fact that most of the effects of changes in supplyside fiscal policies occur only after the first five years.

The results in Table 8 point out that the effect of higher productivity on higher saving and investment on productivity, growth, and inflation is far from instantaneous. In fact, even if an optimal fiscal policy were to be implemented immediately, we would not expect it to have a noticeable effect on slowing inflation for at least two years. In fact, it is often five years or even more before the full effect of higher saving is translated into benefits for the entire economy.

In fact, it is interesting to note that the initial effect of these tax cuts is to raise inflation, just as would be the case in a traditional demand-side model. This occurs because the demand elementshigher consumption and investment - are activated before the supply elements - higher productivity and lower wage rates-work 
TABLE 8

Annual Comparisons of Alternative Scenarios

$1981 \quad 1982 \quad 1983 \quad 1984 \quad 1985 \quad 1986 \quad 1987 \quad 1988 \quad 19891990$

Real GNP, $\%$ Change

Baseline $\quad \begin{array}{llllllllll}2.0 & 5.2 & 3.6 & 0.0 & 1.5 & 3.0 & 3.6 & 3.6 & 3.6 & 3.5\end{array}$

$\begin{array}{lllllllllll}\text { High Growth } & 2.5 & 5.9 & 3.8 & 0.2 & 1.6 & 3.2 & 4.1 & 4.7 & 5.2 & 5.4\end{array}$

$\begin{array}{lllllllllll}\text { Low Growth } & 1.7 & 3.8 & 1.7 & -0.9 & -0.1 & 1.2 & 2.4 & 2.9 & 3.5 & -0.3\end{array}$

Implicit GNP Deflator, \% Change

$\begin{array}{lllllllllll}\text { Baseline } & 9.1 & 8.2 & 8.0 & 7.9 & 7.1 & 6.3 & 6.2 & 6.3 & 6.6 & 6.9\end{array}$

$\begin{array}{lllllllllll}\text { High Growth } & 9.2 & 8.7 & 8.6 & 8.2 & 6.9 & 5.7 & 5.0 & 4.5 & 4.2 & 3.8\end{array}$

$\begin{array}{lllllllllll}\text { Low Growth } & 9.8 & 9.2 & 9.2 & 9.2 & 8.8 & 8.4 & 8.5 & 9.1 & 10.0 & 11.6\end{array}$

Productivity Growth, \% Change

$\begin{array}{lllllllllll}\text { Baseline } & 1.3 & 1.4 & 1.3 & 0.3 & 0.0 & 0.7 & 0.8 & 0.9 & 0.9 & 0.9\end{array}$

$\begin{array}{lllllllllll}\text { High Growth } & 1.3 & 1.7 & 1.8 & 1.1 & 1.2 & 2.3 & 2.9 & 3.4 & 3.9 & 4.2\end{array}$

$\begin{array}{llllllllllll}\text { Low Growth } & 1.2 & 1.5 & 1.1 & -0.7 & -1.4 & -1.5 & -1.9 & -2.4 & -2.7 & -3.0\end{array}$

Ratio of Fixed Business Investment to GNP

$\begin{array}{lllllllllll}\text { Baseline } & 9.3 & 9.8 & 10.8 & 11.2 & 10.8 & 10.8 & 11.0 & 11.1 & 11.1 & 11.0\end{array}$

$\begin{array}{lllllllllll}\text { High Growth } \quad 9.4 & 10.2 & 11.6 & 12.1 & 12.1 & 12.3 & 12.5 & 12.8 & 12.9 & 13.0\end{array}$

$\begin{array}{lllllllllll}\text { Low Growth } & 9.3 & 9.7 & 10.4 & 10.5 & 10.3 & 10.1 & 10.1 & 10.2 & 10.0 & 9.9\end{array}$

Ratio of Government Spending to GNP

Baseline $\quad \begin{array}{llllllllll}36.6 & 36.1 & 35.6 & 36.3 & 36.8 & 36.9 & 36.8 & 36.6 & 36.5 & 36.4\end{array}$ High Growth $36.6 \quad 34.0 \quad 32.2 \quad 31.9 \quad 31.6 \quad 31.1 \quad 30.4 \quad 29.929 .4 \quad 29.9$ $\begin{array}{lllllllllll}\text { Low Growth } & 37.2 & 36.6 & 36.9 & 38.1 & 39.2 & 39.7 & 39.7 & 39.3 & 38.5 & 38.9\end{array}$

Personal Saving Rate, $\%$

$\begin{array}{lllllllllll}\text { Baseline } & 4.5 & 5.1 & 6.6 & 6.6 & 6.5 & 7.6 & 8.8 & 9.7 & 10.3 & 11.1\end{array}$

$\begin{array}{lllllllllll}\text { High Growth } & 5.0 & 5.1 & 6.1 & 5.7 & 5.5 & 6.5 & 8.0 & 9.4 & 10.7 & 12.5\end{array}$

$\begin{array}{lllllllllll}\text { Low Growth } & 3.2 & 3.2 & 3.4 & 2.8 & 2.5 & 3.0 & 3.3 & 3.0 & 2.2 & 0.8\end{array}$ 
their way through the system. However, by 1985 the situation is reversed and by 1990 the inflation rate in the higher growth scenario is almost 3\% below the baseline solution.

It is perhaps not very difficult to convince anyone that a higher rate of growth is preferable to a lower one. However, recently two groups of lower growth advocates have emerged: those who argue that we either cannot or should not produce enough resources necessary to support higher growth, and those who argue that higher growth would be inflationary and hence ultimately destroy that which we set out to accomplish.

The resource question is not a trivial one, but can be solved by an appeal to market economics. The decline in domestic oil production and the huge increases in the volume of oil imports during the past decade has been directly related to the decision by U.S. government officials that we would somehow all be better off if oil prices were not allowed to rise as fast as increasing costs. While the problem with energy reserves is the most virulent, similar problems exist with respect to many other basic industrial commodities. It is imperative that the higher growth scenario be accompanied by adequate supply response in terms of profit margins for those who extract or produce basic materials.

\section{Simulations AND MUlitiplier Estimates}

One way to approach this subject would be to give the usual multiplier estimates for small changes in government spending, personal income tax cuts, corporate tax cuts, and similar measures. Even these estimates can be quite instructive; we have already used this model to show that the Carter tax packages are much more inflationary than the Reagan tax packages. However, the full flavor of the supply-side model cannot really be savored unless we introduce massive changes in fiscal policy, and it is these changes which we report in this section. Specifically, we have prepared three simulations: a) the baseline case with moderate tax cuts and essentially a balanced budget after 1982 , b) a daring experiment in which we cut personal and corporate tax rates in half, and c) the same tax cuts, but combined with enough reductions in transfer payments to balance the budget.

GENERATING A HIGH GROWTH SCENARIO: THE LARGE DEFICIT CASE

The high-growth run is generated by changing the following tax parameters: 
1. Gradual reduction in the corporate tax rate from 0.46 to 0.20 by 1985 . The actual yearly values are:

$\frac{1980}{0.46} \quad \frac{1981}{0.40} \quad \frac{1982}{0.35} \quad \frac{1983}{0.30} \quad \frac{1984}{0.25} \quad \frac{1985 \text { and later }}{0.20}$

2. Depreciation lives for equipment reduced from 10.5 presently to eight years in 1981 and five years in 1982 and thereafter.

3 . Depreciation lives for structures reduced from 23 presently to 18 years in 1981 and 10 years in 1982 and thereafter.

4. Gradual reduction in the average marginal federal personal income tax rate from $24 \%$ to $12 \%$ in equal increments by 1990 .

The revenue losses from these changes are immense, particularly when calculated in 1990 prices. For example, taxable personal income is estimated to be $\$ 3.4$ trillion by 1990 . Thus a cut from $24 \%$ to $12 \%$ in the tax rate would result in a static revenue loss of some $\$ 410$ billion.

The changes in the corporate tax rates are not as great, but they are still substantial. Pre-tax corporate profits are expected to be about $\$ 400$ million by 1990 ; hence, cutting the tax rate from $46 \%$ to $20 \%$ would reduce tax receipts by $\$ 100$ billion. In addition, shortening depreciation lives would lower pre-tax corporate income by $\$ 140$ billion, although since the tax rate is reduced to $20 \%$, this only accounts for an additional $\$ 30$ billion revenue loss per year. In fact, it should be clear that as the corporate tax rate approaches $0 \%$, the length of depreciation lives is no longer of any importance for tax purposes.

These figures indicate a static revenue loss of $\$ 540$ billion per year. Even when compared with a GNP of almost $\$ 7$ trillion and a federal budget of $\$ 1.7$ trillion, the amounts are quite large. This loss amounts to a deficit of $7.7 \%$ of GNP, which is far larget than the postwar record of $4.6 \%$ posted in the recession year of 1975 .

It is usually argued that such static revenue loss estimates are inappropriate, for they fail to consider the higher revenue base raised by faster growth of the economy, higher employment and income, and greater profits. However, this leads to one of the major findings of the supply-side model.

Because lower personal income tax rates generate smaller gains in wage rates and hence smaller increases in unit labor costs and prices, current dollar GNP is only slightly larger in the higher growth scenario than in the baseline case. Real GNP is some $8.6 \%$ higher, since we have defined the high growth alternative to show real GNP rising approximately $1 \%$ per year faster for the nine-year 
period 1981-1990. However, according to our basic results on the trade-off between productivity and inflation, every $1 \%$ increase in productivity results in a $2 \%$ reduction in inflation. Hence in steady state equilibrium, we would expect current dollar GNP to grow $1 \%$ less per year with this higher productivity growth.

The hypothesis that higher growth leads to more inflation is effectively defused by the results given in this report. Indeed, the higher growth scenario is accompanied by lower rather than higher rates of inflation, due to greater productivity and lower wage rate increases both slowing the rise in unit labor costs. Thus we are able to generate realistic alternative scenarios which not only provide for more jobs and greater output, but reduce the rate of inflation as well by redirecting resources toward saving and investment.

Finally, it is clear that one of the major contributors of higher growth in the preferred scenario has been the increase in the investment ratio, which in turn has been brought about through tax incentives for increased saving and investment.

The generalized incentives for investment-lowering the corporate income tax rate and shortening depreciation lives-are well known and have often been suggested for stimulating investment. We have not used an increase in the investment tax credit in this scenario because of our finding that it is not as efficacious. It increases investment only about half as much as an equal reduction in the corporate income tax rate and about $3 / 4$ as much as an equal reduction in depreciation allowances. We have also introduced a net reduction in the capital gains tax by increasing the exclusion from $600 \%$ to $70 \%$ of the total gain, a change which also stimulates investment through raising stock prices and hence lowering the cost of equity capital.

However, one should not neglect the fact that capital markets are fungible - that an increase in saving in any major sector of the economy will result in lower interest rates, greater credit availability, and hence greater investment and productivity. We can achieve these gains not only by stimulating investment directly, but by increasing saving in the personal and govermmental sectors. In particular, we beheve that capital formation can be stimulated by reducing personal as well as corporate income taxes.

Hence in addition to reducing the corporate tax rate to $20 \%$ and restructuring depreciation lives to adjust for inflation, we also favor broad-based personal income tax cuts accompanied by commensurate reduction in government transfer payments. It is the balanced approach - the use of all three legs of the stool-which we feel is essential for balanced low inflationary growth. 